\title{
Regional differences in socio-economic health inequalities in Spain
}

\author{
by \\ Pilar G arcía Gómeza and Angel López Nicolásab* \\ First version March 2004 \\ This version 0 dober 2004
}

a D epartament d'Economia i Empresa and CRES, Universitat Pompeu Fabra, 08005-Barcelona, Spain

b D epartamento de Economía. Universidad Politécnica de Cartagena. 30203-Cartagena, Spain

* Corresponding author. E-mail: angel.lopez@ upf.edu. Address: Departamento de Economía Facultad de Ciencias de la Empresa. Universidad Politécnica de Cartagena. Paseo Alfonso XIII , 50. 30203 Cartagena (Spain). Fax: 9683257 81. This paper derives from the project "La dinámica del estado de salud y los factores socieconómicos a lo largo del ciclo vital. Implicaciones para las políticas públicas", which is supported by the Fundación BBVA. We are grateful to Guillem López and two anonymous referees for useful comments and suggestions. The views expressed in this paper are those of the authors and not necessarily those of the funders or the authors' em ployers. 


\begin{abstract}
This paper reports an analysis of income related health inequalities at the Autonomous Community level in Spain using the self assessed health measure in the 2001 edition of the Encuesta Nacional de Salud. We use recently developed methods in order to cardinalise and model self assessed health within a regression framework, decompose the sources of inequality and explain the observed differences across regions. We find that the regions with the highest levels of mean health tend to enjoy the lowest degrees of income related health inequality and vice-versa. The main feature characterizing regions where income related health inequality is low is the absence of a positive gradient between income and health. In turn, the regions where income related health inequality is greater are characterized by a strong and significant positive gradient between health and income. These results suggest that policies aimed at eliminating the gradient between health and income can potentially lead to greater reductions in socio-economic health inequalities than policies aimed at redistributing income.
\end{abstract}

JEL classification: D 63, I12, C21

Keywords: Health inequalities; decomposition analysis; Spain. 


\section{Introduction}

The Spanish health care system has been decentralized to an unprecedented extent in the course of the last 25 years. This process of devolution has coincided in time with a major overhaul in the nature of its functions at a national level. Two major features of the nation wide reforms are the introduction of universal coverage and the development of the primary care network as the basic pillar of the system, shifting emphasis away from hospital care. The process of devolution has not been homogeneous, however. Some regions were transferred health care responsibilities as early as 1981 while as many as 10 out of the 17 autonomous regions were transferred in 2002. It is widely accepted that this fragmented process of devolution has interfered with the aim of guaranteeing the system's equity and quality [3]. In this paper we aim to investigate the degree of income related inequality across regions for the Spanish population in the year 2001. For this objective, we use recently developed methods in order to model health status, decompose the sources of inequality of health over income and explain the observed differences between regions. We shall use data from the 2001 Encuesta Nacional de Salud, a health survey which is representative at the regional level and contains data on health status, income and other socio-economic characteristics. Our contention in this paper is that the heterogeneity of resources and organizational arrangements across regions might reflect in differences in the joint distribution of health and income after controlling for other correlates of health such as demographic structure, education, activity status etc. In this paper we set out to measure such differences. Our results indeed show that there are important geographical disparities: País Vasco, Navarra and La Rioja are the regions with the highest levels of mean health and simultaneously enjoy the lowest degree of income related health inequality. By contrast, Murcia is the least favoured region in that its population report one of the lowest levels of mean health and 
suffers the greatest degree of income related health inequality. Other territories where income related health inequality is high relative to País Vasco include rich regions such as Madrid, Baleares and Catalonia. The main feature characterizing regions where income related health inequality is low is the absence of a positive gradient between income and health. In turn, the regions where income related health inequality is greater are characterized by a strong and significant positive gradient between health and income.

Section 2 briefly summarizes the characteristics of the Spanish health care system and provides background references within the Spanish literature. Section 3 presents the methodology that we adopt for the measurement and modeling of health, the measurement of socio-economic health inequality and the explanation of its changes across space. Section 4 describes the data set employed throughout the analysis. Section 5 presents the empirical results, section 6 discusses the policy implication of the results and section 7 concludes.

\section{Regional differences in health care arrangements at the start of the XXIth century in Spain}

By the start of the century health responsibilities were devolved to 7 regions with governments run by different political parties, with different demographic structures and traditions in the industrial organization of health care. This is compounded by the fact that País Vasco and Navarra have a distinctive fiscal arrangement which grants them more degrees of freedom in expenditure decisions. These two regions have given public coverage to dental care for children since the end of the 80 's, for instance. The remaining 10 regions were managed by a central body until 2002, the INSALUD, but this did not guarantee a 
greater degree of homogeneity. Indeed, one source of potential differences arose from the calendar of devolution. Catalonia (1981), Andalucía (1984), País Vasco and Valencia (1988), Navarra and Galicia (1991) and Canarias (1994) gained responsibilities first, but the remaining 10 regions have had a regional government for a long period before they have gained health responsibilities. It has been argued [3] that the coexistence of a central regulating body and a regional government generated frictions which have led to an uneven implementation of reforms. The European Observatory on Health Care Systems [3] cites the case of the primary care reforms in Galicia, which met opposition from the regional government from the mid 80 's to the mid 90 's. Galicia finally gained health care responsibilities in 1991 but the results from these frictions are present in recent data. By 2000, $81 \%$ of the Spanish population on average were covered by the new primary care network but the fraction was $50 \%$, the lowest, in Galicia. It is important to stress that benefiting from the reformed primary health care network is important for equity purposes. The old network consisted of isolated outlets where general practitioners were typically available for two and a half hours per day [3]. Unsurprisingly, given the low quality of public primary care, the rich turned to private outlets except when hospital care was needed. In constrast, the new network comprises team based practices staffed by doctors and nurses who have received specific training in family medicine and whose activities not only included curative care, but also preventive care, health promotion, follow up of patients and services targeted to particular population groups such as the mentally ill, drug users etc.

The uneven development of the primary health care system reflects in many indicators of primary health care coverage displaying variation across regions in 2001. The Ministry of Health [8] provides information for the percentage of the population covered by specific primary health care programs (these programs include, among others, vaccinations against 
flu for elderly people, prevention of heart diseases, care for patients with chronic diseases such as hipertension, COPD, etc). Heart disease prevention, for instance, reached $70.6 \%$ of the target population in Aragón but less than 50\% in Murcia or Extremadura. Similarly, vaccination against flu for over 65's reached 65.2 of the target population in Castilla La Mancha but only $54.3 \%$ in Madrid or 58.4\% in Murcia.

There are also regional differences in the stock of capital available for hospital care. Data from the Ministry of Health [9] reveal that the average number of beds per 100000 inhabitants is 386 but regions such as Andalucía (293.7), Castilla-León (208.75), Valencia (279.09) or Murcia (313) are well below the average. Moreover, the percentage of these beds belonging to the public sector varies remarkably around the Spanish average of $73 \%$ reflecting the unequal extent to which the public sectors contracts out the provision of health care. In this sense Catalonia, at 36.8\%, has the lowest ratio of public to total beds. It is worth mentioning that these disparities in health care infrastructures across regions are not explained by differing degrees of need related to demographics or morbidity and mortality. A study by Puig Junoy and López Nicolás [10] showed that the best regions in terms of the ratio of stock of health care capital to health care need were Navarra, Madrid, Aragón and País Vasco, while Baleares, Extremadura and Galicia were ranked in the lowest positions. Territorial disparities in the supply of preventive services and high technology have also been found in a recent study [5].

Thus the evidence suggests that by 2001 the Spanish health care system presents a good degree of heterogeneity across regions. This does not necessarily lead to regional disparities in health outcomes, because differences in the management of resources and/ or poverty alleviation efforts from other areas of policy making might be more important at generating 
health differences between populations, as pointed out by García Vargas and del Llano Señaris [4]. Nevertheless, Abad and Carreter find important regional disparities in life expectancy in a recent study [1].

Our contribution to the literature focuses in evaluating the extent to which health is unequally distributed over income within each of the regions, controlling for other covariates of health such as demographic structure, education and activity status. The Spanish literature contains relevant antecedents in the topic. Regidor et al. [11, 12, 13] have found a significant pro-rich bias in the relationship between socio-economic class (as defined by several combinations of education levels and occupation) and outcomes such as the SF-36 instrument, self-assessed health, prevalence of chronic diseases, standardised death rates and risky habits. Van Doorslaer et al. [19] use data from the Encuesta Nacional de Salud 1987 and find that there is pro-rich inequality in self-assessed health as measured by the concentration index. Van D oorslaer and Koolman [17] again find a significant degree of prorich inequality using data from the 1996 Spanish wave of the European Community Household Panel. Thus we know that, on average, there is pro-rich socioeconomic inequality in health outcomes in Spain. What we do not know, however, is how the degree of pro-rich socioeconomic inequality varies across regions. Indeed, Van Doorslaer and Koolman [17] find significant regional effects in the determinants of self assessed health and the contributions to health inequality. This suggests that fully disaggregated regional analysis is bound to offer interesting evidence. 
A word of caution needs to be raised, however. Differences in the state of health care system across regions might translate into differences in income related health inequalities through differential economic barriers to access or differential quality of services or a combination of both. That is, given that differences operate at several levels (primary and secondary care, extent of private provision etc.), it is not possible to attribute differences in income related health inequality to a particular health care arrangement. The unequal development of reforms would in principle allow the evaluation of their impact as a quasi-experiment, but this is not the scope of the present paper, where we look at an indicator which reflects the compound effects of all relevant disparities as far as they bear an impact on the joint distribution of health and income.

\section{Methods}

\subsection{Measurement of health}

O ur measure of health is derived from the respondent's assessment of his/ her health status during the year previous to the date of the interview. As in many health surveys, information on self assessed health (SAH) in the Encuesta Nacional de Salud is presented in a categorical variable resulting from the following question: "D uring the last 12 months, would you say that your health has been i) very good, ii) good, iii) normal, iv) bad, v) very bad". There are several methods for the cardinalisation of this measure of SAH. A first approach [19, 21] would consist in assuming that $\mathrm{SAH}$ is an underlying latent variable with a standard lognormal distribution and then assigning to each observed SAH category the mid point of the intervals of a standard log normal as defined by the cumulative distribution of observed SAH categories. A natural extension of the underlying latent variable approach would consist in modelling SAH with an ordered probit structure [2,7]. Since an ordered probit does not identify the scale of the latent variable, this procedure requires ex-post rescaling to the interval within which latent SAH is assumed to vary. The problem of ex-post rescaling can be solved by using external information on a generic health measure in conjunction with 
categorical SAH. O ne alternative along this line consists in using the mean value of generic health per SAH category to score latent SAH. In a recent paper [16], Van Doorslaer and Jones compare these alternatives with a new procedure consisting in combining external information on the distribution of a generic measure of health with the distribution of observed SAH in order to obtain the thresholds of generic health that delimit the SAH categories. Given this information, SAH can be modelled as an interval regression and no ex-post rescaling is necessary. Van Doorslaer and Jones [16] show that this is the best procedure in terms of the ability to mimic the distribution of generic health departing from the SAH categories and the set of covariates used in the interval regression model. Subsequently this procedure has been used by Van Doorslaer and Koolman [17] in their analysis of health inequalities in the European Union. We adopt this method for this paper and, in common with their approach, we will use information on the empirical distribution of the Health Utility Index (HUI) in the 1994 Canadian National Population Health Survey. Thus, we assume that there is a stable mapping from HUI to the latent variable that determines reported SAH and that this applies not only for Canadian, but also for Spanish individuals. Therefore, we compute the cumulative frequency of observations for each category of SAH and then find the quantiles of the empirical distribution function for HUI in the NPHS that correspond to these frequencies. Chart 1 presents the cumulative frequencies of the distribution of SAH and the corresponding quantiles in the distribution of HUI.

\begin{tabular}{|lll|}
\hline SAH & Cum. Frequency & HUI quantile \\
\hline \hline Very bad & 1.64 & 0.34 \\
Bad & 7.20 & 0.68 \\
Average & 29.70 & 0.86 \\
Good & 84.77 & 1 \\
Very Good & 100.00 & 1 \\
\hline Chart 1. Cumulative frequencies of SAH and quantiles of HUI
\end{tabular}

Therefore, an individual who reports very bad health will be assumed to have a HUI level that belongs to the interval $[0,0.34]$. Similarly, the intervals for the remaining SAH categories are $(0.34,0.68]$ for the "bad" category, $(0.68,0.86]$ for the "average" category and $(0.86,1]$ for the "good" and "very good" categories. 
In short, our procedure to measure health consists in using the predictions for the latent variable in the following econometric model

$$
\begin{aligned}
& y_{i}^{*}=\beta_{1}+\sum_{k=2}^{K} \beta_{k} x_{k i}+u_{i} \\
& y_{i}=j \text { if } \mu_{j-1}<y_{i}^{*} \leq \mu_{j} j=1,2,3,4
\end{aligned}
$$

where $u_{i}$ is a standard normal random error term, $j=1,2,3,4$ denote the very bad, bad, normal and good or very good SAH categories and $\mu_{\mathrm{j}}$, are the thresholds whose values are given by the intervals above. Therefore the health measure used in the subsequent analysis for the ith individual is given by

$$
\hat{y}_{i}^{*}=\hat{\beta_{1}}+\sum_{k=2}^{K} \hat{\beta_{k}} x_{k i}
$$

The linearity of the resulting health measure, which is expressed in HUI units, is a useful feature at the time of computing and decomposing inequality measures as we will see below.

\subsection{Measurement and explanation of inequality}

The literature on health inequalities has recently adopted a standard tool for the measurement of income related health inequalities: the concentration index (CI) of health on income [22]. The concentration index has a similar interpretation to the more familiar Gini index for pure health inequality. In fact, the two inequality measures differ in the fact that the ranking variable is income (CI) rather than health (Gini). As the Gini index, the standardized CI ranges between -1 and 1 . A value of -1 would mean that all health is concentrated in the poorest person, whereas a value of 1 would result if all health were concentrated in the richest person. A value of zero would mean that health is equally 
distributed over income in the sense that the pth percentage of the population ranked by income has exactly the pth percentage of total health for any p. Concentration indices have been used in studies for the Spanish population previously [14, 15, 18, 19]. Rodríguez et al [14] and Van D oorslaer et al [18] measure the degree of equity in the financing and delivery of health care by means of such indices and related measures such as the Gini and Kakwani indices, while Van Doorslaer et al [19] use them for the measurement of socioeconomic health inequality.

Suppose we are interested in calculating the CI coefficient for a measure of health using individual data in a sample from the population of interest. Let $\mathrm{y}_{\mathrm{i}}$ denote a measure of health for the $\mathrm{I}^{\text {th }}$ individual, $\mathrm{i}=1,2, \ldots \mathrm{N}$, and $\mathrm{R}_{\mathrm{i}}^{\prime}$ denote the cumulative proportion of the population ranked by income up to the $\mathrm{I}^{\text {th }}$ individual (their 'relative income rank').

Ignoring, for expositional purposes, the fact that in general sampling weights will be necessary, the CI of health on income is given by (see e.g. [16]),

$$
C I=\left(\frac{2}{\bar{y}}\right) \operatorname{cov}\left(y_{i}, R_{i}^{\prime}\right)
$$

where $\bar{y}=E\left(y_{i}\right)$. Now let $\mathrm{y}_{\mathrm{i}}$ be given by the following linear regression model

$$
y_{i}=\beta_{1}+\sum_{k=2}^{K} \beta_{k} x_{k i}+\varepsilon_{i}
$$

where $\mathrm{k}$ is the number of regressors $(\mathrm{x})$. By substituting this for $\mathrm{y}_{\mathrm{i}}$, the CI of $\mathrm{y}$ can be written as [20], 


$$
C I=\sum_{k=2}^{K}\left(\beta_{k} \frac{\bar{x}_{k}}{\bar{y}}\right) C I_{k}^{\prime}+\left(\frac{2}{\bar{y}}\right) \operatorname{cov}\left(\varepsilon_{i}, R_{i}^{\prime}\right)
$$

The first term in brackets is the elasticity of $\mathrm{y}$ with respect to $\mathrm{x}_{\mathrm{k}}$ evaluated at the sample means $\left(\bar{x}_{k}\right.$ and $\left.\bar{y}\right)$ and $\mathrm{CI}_{\mathrm{k}}^{\prime}$ denotes the concentration index of $\mathrm{x}_{\mathrm{k}}$ against income. Thus this inequality measure can be decomposed into an "explained part" and an "unexplained part". The "explained" part can be usefully broken down into the contributions of individual explanatory variables. As for the "unexplained" part, it is a scaled measure of the covariance of the residuals in the regression model with the position of the individual in the distribution of income. As such, the unexplained part should be zero if the regression model contains income as an explanatory variable [6].

As explained in section 3.1, our health measure is a linear combination of the explanatory variables included in the interval regression model. Given the nature of the dependent variable in the latter model, no residuals can be computed so the decomposition reduces to the deterministic term in equation (5). Moreover, if we define the estimated health elasticity with respect to determinant $\mathrm{k}$ as

$$
\hat{\eta}_{k} \equiv \frac{\hat{\beta_{k}} \bar{x}_{k}}{\mu}
$$

then we can rewrite the decomposition in a way such that the CI is just a weighted sum of the inequality in each of its determinants, with the weights equal to the elasticities. That is,

$$
C \hat{I} \equiv \sum_{k} \hat{\eta_{k}} \hat{C} I_{k}
$$


As mentioned by Van D oorslaer and Koolman [17], the decomposition also clarifies how each correlate of health contributes to total income-related health inequality: this contribution is the result of (i) its impact on health, and (ii) how unequally distributed over income it is.

\subsection{Decomposing inequality between Autonomous Communities}

As put into practice by Van Doorslaer and Koolman [17], we have used the approach suggested by Wagstaff et al. [20] in order to decompose the difference in inequality between Autonomous Communities. The method is a derivation of the well known Oaxaca decomposition whereby the difference between the CI's of community $i$ and community $j$ can be written as

$$
\Delta C I=C I_{i}-C I_{j}=\sum_{k} \eta_{k j}\left(C I_{k i}-C I_{k j}\right)+\sum_{k} C I_{k i}\left(\eta_{k i}-\eta_{k j}\right)
$$

Then, the contribution of any variable to the difference in the income-related health inequality is decomposed as:

$$
\Delta C I_{k}=\eta_{k j}\left(C I_{k i}-C I_{k j}\right)+C I_{k i}\left(\eta_{k i}-\eta_{k j}\right)
$$

In practice, for each region, we shall compute the differences in inequality (and contributions toward such difference) with respect to the region with the smallest level of inequality, País Vasco. Moreover, in order to assess the relative importance of the inequality versus the health elasticity component in the contribution of each variable, we also compute the relative excess elasticity compared to País Vasco, i.e. $\left(\eta_{\mathrm{ki}}-\eta_{\mathrm{kj}}\right) / \eta_{\mathrm{kj}}$, and the relative excess inequality, $\left(\mathrm{CI}_{\mathrm{ki}}-\mathrm{CI} \mathrm{I}_{\mathrm{kj}}\right) / C \mathrm{I}_{\mathrm{kj}}$ 


\subsection{Statistical Inference}

Many of the statistics that we are going to report are non-linear functions of the data whose sampling distributions are hard to obtain. For this reason we shall use bootstrapping methods in order to derive standard errors. The bootstrap estimates for standard errors are computed following the fivestep approach used by Van D oorslaer and Koolman [17]. The number of replications has been set to 500 .

\section{Data and variable definitions}

We use the 2001 edition of the Encuesta Nacional de Salud. This is nation wide survey collecting information on health and socioeconomic characteristics of individuals. The survey contains separate adults (16+) and children samples. The analysis in this paper is based on the adult sample. The sampling scheme is a complex multi-stage stratified process whereby primary strata are Autonomous Communities and, within the latter, sub-strata are defined according to residence area population size. Within substrata, municipalities (primary sampling units) and sections (secondary sampling units) are selected according to a proportional random sampling scheme. Finally individuals are randomly selected from the sections. The survey documentation includes weighting factors that correct for the fact that the number of observations within the primary strata is not proportional to actual population. We use these weights whenever a nationwide statistic is computed.

The information contained in the data files do not allow the identification of all the primary sampling units (because municipalities with a population below 100000 are not identified). 
Similarly, information about the secondary sampling units is omitted so it is impossible to control for cluster effects at either the municipality level or the section level.

The ranking variable is total monthly income earned by the household. In the ENS this is measured as a categorical variable with 6 response categories. The midpoint of each income group was attributed to all households in the category and this is subsequently divided by an equivalence factor equal to (number of household members) ${ }^{0.5}$, to adjust for differences in household size.

The initial ENS sample included 26265 individuals from all the Autonomous Communities, although the 399 observations from Ceuta and Melilla were dropped. From the remaining 25866, we have dropped 66 because self assessed health was not reported, 6532 whose household income was missing, 3954 whose age was missing. A further 38 individuals with missing values for marital status, job status or education are dropped from the sample. As a result, the estimating pooled sample contains 15276, which are divided across Autonomous Communities as follows: 1488 are from Andalucía, 756 from Aragón, 683 from Asturias, 664 from Baleares, 787 from Canarias, 547 from Cantabria, 820 from Castilla-La Mancha, 1134 from Castilla-León, 1324 from Catalonia, 1220 from Valencia, 827 from Extremadura, 1045 from Galicia, 1484 from Madrid, 641 from Murcia, 472 from Navarra, 820 from País Vasco and 564 from La Rioja.

\section{Empirical results}

\section{1 Measuring and decomposing inequality by Autonomous Community}


As discussed in section 3.1, we specify and estimate an interval regression model for the level of SAH inspired in the specification used by Van D oorslaer and Koolman [17]. It is useful to stress that this is not a structural model for health and therefore its estimates cannot be given a causal interpretation. However, it might be interpreted as a reduced form static model of demand for health whose estimates provide an indication of how exogenous changes in health determinants can affect the degree of socioeconomic inequality in health. The explanatory variables in this model are i) the logarithm of equivalent household income; ii) 14 age-sex categories corresponding to age groups 16-19, 20-24, 25-29, 30-34, 35-39, 40-44, $45-49,50-54,55-59,60-64,65-69,70-74,75-79,80+$ for men and women (the omitted category corresponds to a woman aged between 16 and 19); iii) 5 educational categories: university (omitted category), secondary school, primary school, reads and writes and illiterate; v) 4 marital status categories: single (omitted category), married, divorced, widowed; and vi) 5 activity categories: family care (omitted category), employed, pensioner, unemployed and student.

The first row of table 1 contains the mean predicted values for HUI for each of the regions. Note that there are important variations: Navarra, La Rioja and País Vasco are the three regions with the top scores for mean HUI, while at the bottom of the league there are Canarias and Murcia. In its second row, table 1 also shows that the richest regions (in terms of mean equivalised household income) are Asturias, País Vasco, Baleares, Madrid, Navarra and Catalonia, while the poorest regions are Extremadura, Andalucía, CastillaLa Mancha and Canarias. 
The data also shows differences in the demographic structure across regions. The age pyramid is widest at the base in Baleares, Canarias, Andalucía, Valencia and Murcia whereas mean age is greater in Castilla León, Castilla La Mancha, La Rioja and Aragón. There are important disparities in the education levels of the population. Concerning education the data show that in Castilla-La Mancha, Canarias, Extremadura and Andalucía more than 13\% of the population have not completed primary school. At the other extreme, País Vasco has the highest proportion of university graduates followed by Madrid, Murcia, Asturias and La Rioja. Concerning marital state, there are important differences too. In Canarias 32\% of the population are single, but in Catalonia the proportion is $10 \%$ smaller. Another important difference is found in employment rates. In Baleares, Catalonia and Madrid the proportion of population who declares to be in employment exceeds 50\% whereas in Andalucía, Asturias, the two Castillas and Extremadura the proportion is below 40\%. The figures for these descriptive statistics for demographics, education, marital status and activity are available from the authors.

The results for Spain from the ECPH reported in Van D oorslaer and Koolman [17] reflect a positive and significant association between the logarithm of equivalised household income and health. However, as can be seen in table 1, where the interval regression results for the separate regional models are presented, in this case the estimates show a somehow heterogeneous pattern. For Navarra, País Vasco, La Rioja, Cantabria, Aragón, Extremadura and Canarias the partial (log) income effect is not significantly different from zero at conventional levels. The concentration of insignificant impacts along the east Cantabric coast (País Vasco, Cantabria) and neighboring regions (Navarra, Aragón and La Rioja) would suggest a sort of common geographical effect. As reported above, these are also the regions 
with the highest mean HUI scores so this would suggest a concave relationship between health and income, with the healthiest regions situated at points where the profile is flat. For the two Castillas, Valencia and Asturias the partial effect of income is significant at the $10 \%$ level and the point estimates are small. In contrast, for Galicia, Murcia, Catalonia, Andalucía, Madrid and Baleares the income effect is greater and clearly significant. The point estimates for Madrid and Baleares have the greatest absolute value. This is a striking result in the sense that Madrid and Baleares are rich regions. Thus, unlike the results reported in Van D oorslaer and Koolman [17], the data do not generally support a negative relationship between the strength of the (log) income effect and the level of regional income per capita.

The patterns of health variations by demographics are similar to the evidence found by Van D oorslaer and Koolman [17] for the 13 European countries. In general women report less health than men all else held equal and for both genders the level of health decreases with age. However, in Aragón, Asturias, Canarias, Valencia and País Vasco there is not a clear association between gender and health reported. Similarly, individuals within the two lowest educational categories (illiteracy and no formal qualifications) report a significantly lower level of health than those with secondary or university education. Also, divorcees tend to report a lower level of health than the rest of individuals. A surprisingly common feature for most of the regions, is the fact that, else equal, widows report a greater level of health than other individuals. Concerning activity status, there are two salient features. On one hand, those in employment tend to report better health than the rest of individuals, although this effect is not significant at conventional levels for quite a few regions, it is particularly strong in País Vasco and Madrid. On the other hand, pensioners tend to report a significantly lower 
level of health in País Vasco, Murcia, Andalucía, Extremadura, Catalonia, Castilla-La Mancha, Cantabria and Baleares.

In table 2 we report the concentration indices of predicted HUI and the explanatory variables. A salient feature is that there is pro-rich health inequality in all regions, with the bootstrapped standard errors showing that the concentration indices are all statistically significant. However, the most prominent feature concerns the striking differences in the level of income related health inequalities across regions. The regions with the highest health levels, i.e Navarra, País Vasco and La Rioja turn out to enjoy the lowest levels of income related health inequalities. At the other extreme Murcia has the highest concentration index, and it is closely followed by Madrid, Baleares and Catalonia. Note that there are also differences in the degree of equivalised household income inequality. The highest level of income inequality is found in Canarias, followed by Andalucía. At the other extreme Asturias, Navarra and País Vasco enjoy the lowest levels of income inequality. The concentration indices for the agesex controls reveal that older people are concentrated in low income groups with and important difference across genders because, for women, the concentration into low income groups starts operates at earlier ages, i.e. while for males the age at which concentration into low incomes takes place is $60+$, for women it is $45+$. As one might expect, individuals with the lowest educational attainments (illiteracy, basic literacy and primary schooling) are concentrated into low incomes and those with secondary schooling or university degrees are concentrated in high incomes. In all regions there is pro-poor inequality in the distribution of widowhood, as it might be expected from the fact that many individuals in this collective have a non-contributory pension as their main source of 
income. Finally note that pensioners and the unemployed are concentrated within low incomes, whereas, as expected, employment is concentrated among high incomes.

Next we analyse the contributions of the explanatory variables to the degree of income related health inequalities. These contributions are presented in table 3. Part of the inter regional differences in the degree of income related health inequality are due to differences in the age-gender structure of the population and the fact that there is heterogeneity across regions in both the joint distributions of age and gender with equivalised household income and the partial effects of age and gender on health. We can standardize the concentration index by age and gender by substracting the contributions of age and gender from the raw concentration index. The resulting figures are presented in the second row of table 3. In general the standardized indices reveal the same pattern as the raw counterparts, with Baleares, Catalonia, Madrid and Murcia among the greatest levels of standardised inequality and Navarra, País Vasco and La Rioja at the opposite extreme. In the case of Baleares, the standardized index is greater than the raw one. As we mentioned before, the population in this region is younger than on average, so this result suggests that the degree of income related health inequality would be greater if Baleares had a population with the average Spanish age-sex distribution. On the contrary, the standardized indices for Madrid, CastillaLeón, Castilla-La Mancha, Navarra, La Rioja and Aragón are notably smaller than their raw counterparts. There are striking variations in the contributions of the age-sex structure to the overall level of income related health inequality. For instance, it accounts for more than $64 \%$ of the raw index in La Rioja and more than 50\% in CastillaLeón and Aragón. On the other hand, it barely accounts for about 15\% of the raw index in Murcia, Extremadura, Catalonia and Cantabria. The distribution of educational attainments accounts for a substantial part of 
income related health inequalities in some regions. In Canarias, Murcia, Extremadura and La Rioja they contribute to roughly $20 \%$ of the raw concentration index. Note that these are regions where the distribution of education is more unequal: Canarias and Extremadura have a high proportion of individuals with less than primary schooling and Murcia and La Rioja have a high proportion of university graduates. At the other extreme, in Andalucía, Asturias, Baleares, the two Castillas, Madrid and Navarra, education accounts for a small share of the concentration index. Moreover, in the case of País Vasco, education contributes negatively to income-related health inequality. Although the contribution of marital status is small in general, it is relatively high in some regions such as Asturias - $20 \%$ of the CI- and Baleares or País Vasco and Navarra-, among others, where inequality in marital status actually reduce the CI.

By far the most important contributors to income related health inequality are equivalised household income itself and activity status. In Andalucía, Baleares and Madrid the contribution of income exceeds 60\%. For Catalonia, Galicia, Asturias and Murcia the contribution is in line with the Spanish average. For some the regions where we cannot reject that the partial effect of income is zero such as Aragón, Cantabria, Navarra, La Rioja and País Vasco the point estimate of the contribution is small (G raph 1 plots the elasticity of HUI with respect to log income against the $\mathrm{G}$ ini index of log income in order to gauge the strength of the two components for the contribution of income). Concerning the contribution of employment status, income related inequalities in the distribution of employment and pensioner status are the main drivers. In País Vasco these two factors together account for more than income-related health inequality itself. That is, if the rest of covariates had their effect neutralized, the CI for País Vasco would be a greater. In Baleares, 
Castilla La Mancha, Extremadura, Catalonia, Murcia País Vasco, La Rioja and Cantabria, the unequal distribution of pensioner status accounts for a large fraction of income related inequality on predicted HUI.

\subsection{Decomposing excess inequality}

Which are the factors that generate more income related health inequality in some regions? Table 4 provides the answer by showing the contribution of each explanatory variable to the excess inequality of each region with respect to the region with the lowest CI, País Vasco. We note that an overwhelming fraction of excess inequality, is attributable to income in Andalucía, Asturias, Baleares, Catalonia, Galicia, Madrid and Murcia. Note that among the latter there are the top four regions in terms of CI. For the rest of regions the contribution of income to excess inequality ranges between 37\% for Castilla-La Mancha and 14\% for Cantabria. The contribution of population structure is relatively unimportant in the regions with most inequality. In Murcia it accounts for $9 \%$, in Catalonia $12 \%$ and in Baleares the population structure actually reduces excess inequality with respect to País Vasco. In contrast, the contribution of population structure is important in regions whose degree of inequality is close to País Vasco. In Navarra it accounts for $180 \%$ of the difference, and in Aragón it accounts for $56 \%$. The contribution of education attainments exceeds $50 \%$ in Canarias, and Extremadura and is above 25\% for other regions with a high CI such as Murcia, Catalonia and Galicia. Note that in another region with a high CI, Madrid, the contribution of education to excess inequality is less than $5 \%$. When assessing the contribution of employment status to excess inequality, note that income related health inequality in País Vasco is attributable to nearly exclusively (income related inequality) employment status. Therefore, it is not surprising to find that the contribution to excess 
inequality is negative for some regions such as Asturias, the two Castillas and Valencia, Galicia and Madrid. In contrast, the unequal distribution of employment stata exacerbates inequality with respect to País Vasco in Baleares, Extremadura and Cantabria.

\section{Discussion}

Let us now turn to the implications for policy prescriptions that one might draw from these empirical results. The evidence suggests that, in order of importance, income, employment status and education are the most important drivers of differences in income related health inequality across regions. For the contribution of each of these factors there are two components: its effect on health as measured by the elasticity and its degree of income related inequality. Thus policies aimed at reducing income related health inequality could be directed to either reducing the impact on health of these factors or to altering the distribution of these factors (or both). That is, for the case of income, policies could be directed towards eliminating the positive gradient between health and income (as it occurs in País Vasco and other regions, where the gradient is null) or to make income more equally distributed. In order to gauge which of the two courses of action would potentially lead to a greater reduction in inequality it is useful to present the relative differences (with respect to País Vasco) of health elasticities and concentration indices for each of the regressors. Table 5 shows these figures and the general message that can be inferred is that differences in elasticities are much more striking than differences in the unequal distribution of the correlates of health. Take the case of Murcia. With a CI nearly four times greater than that of País Vasco, this is the region with the greatest degree of income related health inequality and income accounts for $47 \%$ of the "excess inequality" with respect to País Vasco. However, the degree of inequality in the distribution of income in Murcia is only $7 \%$ greater than in 
País Vasco. The difference is therefore driven by the size of the elasticities: in Murcia the elasticity is 23 times greater than in País Vasco. This suggests that, if differences in socioeconomic inequalities are to be reduced towards the País Vasco benchmark, investigating why the health-income gradient is steeper in Murcia and correcting the causes can be more effective than making income more equally distributed. The case of Murcia is representative of the rest of regions with high degrees of income related health inequalities. Furthermore, for the other drivers of inequality it is also evident that the differences in elasticities are more important than the differences in how unequally distributed are these factors. While the scope of this paper consists primarily in providing an empirical account of income related inequalities in $\mathrm{SAH}$, it is interesting to suggest ways in which the causes for the differences in the gradient between health and income might be ascertained. In order to do so, we present a simple plot of the elasticity of HUI to income against the regional indices of public health care infrastructure adjusted by need derived by Puig-Junoy and López Nicolás [10]. Graph 2 shows a clear inverse relationship among these two magnitudes, suggesting that differences in health care infrastructure might play an important role in understanding differences in income related health inequality.

\section{Summary and conclusion}

In this paper we have applied recently developed methodologies [17] to measure and explain the differences in the degree of income related health inequality across Spanish regions. The results reveal important geographical differences. País Vasco, Navarra and La Rioja are the regions with the highest levels of mean health and simultaneously enjoy the lowest degree of income related health inequality. By contrast, Murcia is the least favoured region in that its population report one of the lowest levels of mean health and suffers the greatest degree of 
income related health inequality. Other territories where income related health inequality is high relative to País Vasco include rich regions such as Madrid, Baleares and Catalonia.

The main feature characterizing regions where income related health inequality is low is the absence of a positive gradient between income and health. Nevertheless, even in these regions there is income related health inequality operating through inequality of employment status (País Vasco, Cantabria and Extremadura) or age-sex structure (La Rioja, Navarra, Aragón) over the distribution of income. In turn, the regions where income related health inequality is greater are characterized by a strong and significant positive gradient between health and income. In some cases this is reinforced by the effects of education (Catalonia, G alicia and Murcia).

In similarity to the results for 13 European countries reported in Van Doorslaer and Koolman [17], we do not find substantial differences in the degree of income inequality across regions, so the differential contributions of income to socio-economic health inequalities are ascribed to heterogeneity in the elasticities of health with respect to income across regions. This can be generalized to the other drivers of income related health inequalities. In this sense the policy implications of these results are similar in nature to Van D oorslaer and Koolman [17]: policies aimed at eliminating the gradient between health and income can potentially lead to greater reductions in socio-economic health inequalities than policies aimed at redistributing income. Before being able to formulate these types of policies, however, it is necessary to obtain evidence on the causal pathways between health and income. 


\section{References}

1. Abad Díez J M and Carreter Ordóñez C (2002). Indicadores sanitarios por Comunidades Autónomas. Informe SESPAS 2002.

2. Cutler D and Richardson E (1997) Measuring the Health of the United States Population. Brooking papers on economic Activity. Microeconomics 1997:217-282

3. European Observatory on Health Care Systems (2000). Health Care Systems in Transition. Spain

4. García Vargas J and del Llano Señaris J (2003). El SNS después de las transferencias: ¿seguirá siendo un sistema? Fundación Encuentro. Informe España 2003. Madrid

5. González B, Urbanos R M and Ortega P (2004). Oferta pública y privada de servicios sanitarios por Comunidades Autónomas. Gaceta Sanitaria 18 (Supl1): 82-89

6. Gravelle H (2003). Measuring income related inequality in health: standardisation and the partial concentration index. Health Economics 12: 803-819

7. G root W (2000). Adaptation and scale of reference bias in self-assessment of quality of life. Journal of health economics 19: 403-420

8. Ministry of Health (2002). Atención Primaria en el INSALUD: Diecisiete años de Experiencia. Ministerio de Sanidad y Consumo. Subdirección General de Atención Primaria. Madrid.

9. Ministry of Health (2002). Asistencia especializada. Actividad 2001. Ministerio de Sanidad y Consumo. Subdirección G eneral de D esarrollo. Madrid.

10. Puig Junoy J and López Nicolás A (1995). Assessing Health Care Infrastructure at the Regional Level: a Statistical Approach. Applied Economics Letters 2: 463-466.

11. Regidor E, Gutiérrez-Fisac J L, Rodríguez C, de Mateo S and Alonso I (1995). Las desigualdades sociales y la salud en España. La salud y el sistema sanitario en España. Informe SE SPAS 1995: 19-43.

12. Regidor E, Gregorio B, de la Fuente L, Domingo A, Rodriguez C and Alonso J (1999). Association between educational level and health related quality of life in Spanish adults. Journal of Epidemiology community Health 53: 75-82

13. Regidor E, Gutiérrez-Fisac JL, D omínguez V, Calle M E and Navarro P (2002). Comparing social inequalities in health in Spain: 1987 and 1995/ 98. Social Science and Medicine 54: 1323-1332.

14. Rodriguez M, Calonge S and Reñé J (1993). Spain in Equity in the Finance and Delivery of Health Care. An international perspective. Rutten F, Van Doorslaer and Wagstaff (eds.). Oxford University Press. New Y ork

15. Urbanos R (2001). Measurement of Inequity in the D elivery of Public Health Care: Evidence from Spain (1997). Fedea. D ocumento de Trabajo 2001-15. 
16. Van D oorslaer $E$ and Jones A (2003) Inequalities in self-reported health: validation of a new approach to measurement. Journal of Health Economics 22: 61-87

17. Van Doorslaer E and Koolman X (2004) Explaining the differences in incomerelated health inequalities across European countries. Health Economics 13: 609-628

18. Van D oorslaer E and Wagstaff A (1999). Equity in the finance of health care: some further international comparisons. Journal of Health Economics 18: 263-290

19. Van Doorslaer E, Wagstaff A, Bleichdrodt $H$ et al (1997). Income-related inequalities in health: some international comparisons. Journal of Health Economics 16: 93-112

20. Waggstaff A, Van Doorslaer E, Watanabe N (2003). On decomposing the causes of health sector inequalities with an application to malnutrition inequalities in Vietnam. Journal of Econometrics 112: 207-223

21. Waggstaff A and Van D oorslaer E (1994). Measuring inequalities in health in the presence of multiple-category morbidity indicators. Health Economics 3: 281-291

22. Waggstaff A, Van Doorslaer E and Paci P (1989). Equity in the finance and delivery of health care: some tentative cross-country comparisons. Oxford Review of Economic Policy 5: 89-112 
Table 1: Mean predicted HUI, mean log income and Health equations: interval regression coefficients per region

\begin{tabular}{|c|c|c|c|c|c|c|c|c|c|c|c|c|c|c|c|c|c|}
\hline & dalucía & agón & turias & Aleares & anarias & antabria & $\begin{array}{l}\text { Castilla La } \\
\text { Mancha }\end{array}$ & $\begin{array}{l}\text { Castilla } \\
\text { León }\end{array}$ & Catalonia & Valencia & Extremadure & Galicia & Madrid & Murcia & Navarra & País Vasco & La Rio \\
\hline $\begin{array}{c}\text { Mean } \\
\text { predicted } \\
\text { HUI }\end{array}$ & 2 & 0 & & 5 & 3 & 363 & 1 & 0,863 & 350 & 5 & 1 & 54 & 9 & 848 & 1 & 0 & 89 \\
\hline $\begin{array}{l}\text { Mean Log } \\
\text { Income }\end{array}$ & 11276 & 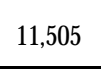 & 0 & 4 & 11,331 & 11,455 & 7 & 11,387 & 4 & 11,403 & 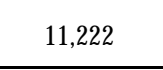 & 11,413 & 11,573 & 1,377 & 14 & 4 & 39 \\
\hline Constant & 0,4357 & 8063 & 5911 & 1494 & 0,6607 & 0,8528 & 0,7168 & 0,7403 & 0,4615 & 0,7025 & 0,7121 & 0,4875 & 0,2090 & 0,4317 & 9998 & 8635 & 8704 \\
\hline Log Income & 0,0396 & 084 & 0278 & 579 & 172 & 0,0059 & 0,0163 & 0,0157 & 0380 & $=$ & 0,0122 & 0,0329 & 0,0553 & 79 & $-0,0053$ &, 0016 & 49 \\
\hline F20-24 & $-0,0234$ & 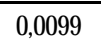 & $1+4$ & 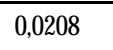 & 0,0032 & 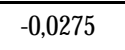 & $-0,0324$ & 0011 & -0 & 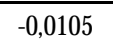 & 2 & 0,01 & t & $-0,0004$ & 5 & $-0,0211$ & 103 \\
\hline F25-29 & $-0,0091$ & 027 & 289 & 17 & & & & 0110 & & & & & & & & & 0064 \\
\hline F30-34 & $-0,0201$ & 0,0107 & $-0,0377$ & $-0,0124$ & 90 & $-0,0060$ & $-0,0064$ & $-0,0050$ & $-0,0204$ & -0 & & 15 & 37 & 16 & 0392 & & 35 \\
\hline F35-39 & $-0,0496$ & $-0,0292$ & 0294 & $-0,0129$ & & $-0,0632$ & 0,0086 & $-0,0313$ & $-0,0412$ & $-0,0039$ & 58 & 6 & & & 0,0006 & &, 0182 \\
\hline F40-44 & $-0,0661$ & 030 & 76 & 55 & & & 60 & $-0,0277$ & & & & & & & 20 & & 0142 \\
\hline F45-49 & -0 & $-0,0405$ & 72 & $-0,0624$ & 0, & $-0,0339$ & $-0,0299$ & $-0,0170$ & $-0,0445$ & $-0,0402$ & 0,0112 & $-0,0218$ & $-0,0748$ & $-0,0382$ & $-0,1091$ & $-0,0527$ & $-0,0239$ \\
\hline F50-54 & $-0,0708$ & $-0,0435$ & 0747 & $-0,0465$ & $-0,027$ & $-0,0674$ & $-0,0057$ & $-0,0455$ & $-0,0774$ & $-0,0466$ & $-0,0625$ & $-0,0205$ & & $-0,0551$ & $-0,0666$ & & $-0,0304$ \\
\hline F55-59 & $-0,1461$ & $-0,0540$ & 709 & $-0,0253$ & $-0,0$ & -0 , & $-0,0886$ & $-0,0460$ & & -0 & -0, & -0, & & 34 & 06 & & 96 \\
\hline F60-64 & & & & 0 , & & & $-0,0$ & -0, & & & & $-0,0$ & -0, & 0,0 & $-0,0526$ & & \\
\hline F65-69 & $-0,0939$ & $-0,0379$ & $-0,0722$ & $-0,0889$ & $-0,0610$ & $-0,0925$ & $-0,0636$ & $-0,1156$ & $-0,0191$ & & $-0,0396$ & $-0,0691$ & $-0,0755$ & 0,0230 & $-0,0660$ & 28 & $-0,0581$ \\
\hline F70-74 & $-0,1491$ & $-0,1028$ & $-0,0677$ & $-0,0584$ & & $-0,0813$ & $-0,1511$ & $-0,1603$ & $-0,0652$ & & $-0,0539$ & $-0,0496$ & 295 & $-0,0065$ & 43 & & $-0,0516$ \\
\hline F75-79 & $-0,0518$ & $-0,0584$ & 1834 & $-0,0326$ & $-0,0911$ & $-0,0706$ & $-0,0503$ & $-0,0998$ & $-0,0934$ & & $-0,0697$ & & & & $-0,0534$ & & $-0,1228$ \\
\hline F80 & $-0,0989$ & $-0,1309$ & $-0,0817$ & $-0,0219$ & $-0,0788$ & $-0,0626$ & $-0,1905$ & $-0,1434$ & $-0,1044$ & $-0,0818$ & $-0,0659$ & $-0,0917$ & $-0,1294$ & $-0,0589$ & $-0,1058$ & $-0,0380$ & $-0,0730$ \\
\hline M16-19 & $-0,0049$ & $-0,0100$ & 0,0046 & 0,0427 & 0,0208 & $-0,0466$ & 0,0074 & 0,0110 & $-0,0041$ & $-0,0116$ & 0,0206 & 0,0294 & $-0,0229$ & $-0,0036$ & $-0,0165$ & 14 & 0,0116 \\
\hline M20-24 & $-0,0018$ & $-0,0059$ & $-0,0106$ & 0,0149 & 0,0596 & $-0,0255$ & $-0,0009$ & 0,0021 & 0,0023 & $-0,0215$ & 0,0206 & $-0,0041$ & 0,0115 & 0,0209 & 0,0010 & & 0,0065 \\
\hline M25-29 & $-0,0208$ & $-0,0078$ & $-0,0128$ & 0,0277 & 0,0171 & $-0,0050$ & 0,0037 & $-0,0017$ & $-0,0148$ & $-0,0072$ & 0,0173 & 0,0141 & 0,0010 & 0,0122 & $-0,0114$ & 15 & 0,0152 \\
\hline M30-34 & $-0,0145$ & $-0,0114$ & $-0,0513$ & 0,0154 & 0,0347 & $-0,0067$ & 0,0003 & $-0,0089$ & $-0,0228$ & $-0,0266$ & 0,0280 & $-0,0009$ & $-0,0123$ & 0,0264 & $-0,0222$ & $-0,0322$ & 0,0146 \\
\hline M35-39 & $-0,0483$ & $-0,0068$ & $-0,0304$ & $-0,0122$ & & & 0,0039 & $-0,0139$ & $-0,0093$ & & & $-0,0292$ & $-0,0226$ & 0,0447 & 0,0007 & & 0,0184 \\
\hline M40-44 & $-0,0240$ & $-0,0352$ & $-0,0157$ & 0,0238 & $-0,0029$ & $-0,0417$ & 0,0062 & 0,0054 & $-0,0455$ & $-0,0066$ & 0,0236 & $-0,0076$ & $-0,0100$ & 0,0314 & $-0,0301$ & & 0,0053 \\
\hline M45-49 & $-0,0454$ & $-0,0283$ & $-0,0932$ & $-0,0571$ & $-0,0376$ & $-0,0430$ & 0,0027 & $-0,0345$ & $-0,0351$ & $-0,0268$ & 0,0347 & 0,0001 & $-0,0586$ & 0,0415 & $-0,0076$ & $-0,0090$ & 0,0045 \\
\hline M50-54 & $-0,0657$ & & & $-0,0295$ & & & $-0,0326$ & $-0,0244$ & $-0,0228$ & & & $-0,0213$ & $-0,0215$ & 0,0080 & $-0,0484$ & $-0,0508$ & $-0,0316$ \\
\hline M55-59 & $-0,0405$ & $-0,0291$ & $-0,0952$ & $-0,0608$ & $-0,0038$ & 0,0396 & $-0,0136$ & $-0,0414$ & $-0,0500$ & $-0,0728$ & 0,0471 & $-0,0487$ & $-0,0381$ & 0,0219 & $-0,1156$ & $-0,0661$ & $-0,0215$ \\
\hline M60-64 & $-0,0710$ & $-0,0364$ & $-0,0738$ & 0,0234 & 0,0401 & $-0,0245$ & 0,0037 & $-0,0549$ & 0,0017 & $-0,0586$ & $-0,0103$ & $-0,0145$ & $-0,0575$ & $-0,0467$ & $-0,0122$ & 0,0552 & $-0,0262$ \\
\hline
\end{tabular}




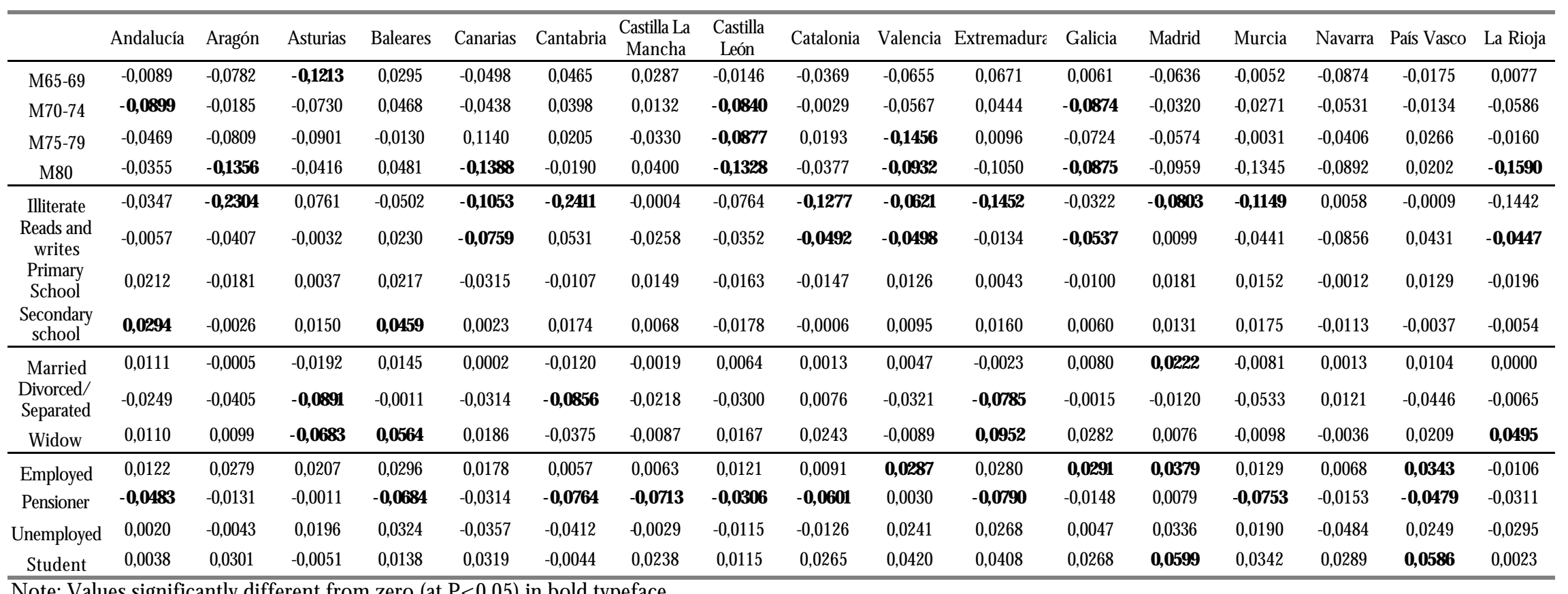

Note: Values significantly different from zero (at $\mathrm{P}<0.05$ ) in bold typeface. 
Table 2: Concentration indices of dependent and independent variables per region

\begin{tabular}{|c|c|c|c|c|c|c|c|c|c|c|c|c|c|c|c|c|c|}
\hline & Andalucía & Aragón & Asturias & Baleares & Canarias & Cantabria & $\begin{array}{c}\text { Castilla La } \\
\text { Mancha }\end{array}$ & $\begin{array}{l}\text { Castilla } \\
\text { León }\end{array}$ & Catalonia & Valencia & Extremadurc & Galicia & Madrid & Murcia & Navarra & $\begin{array}{c}\text { Pasís } \\
\text { Vasco }\end{array}$ & La Rioja \\
\hline $\begin{array}{c}\text { HUI } \\
\text { predicted }\end{array}$ & 0,0192 & 0,0181 & 0,0142 & 0,0235 & 0,0210 & 0,0144 & 0,0171 & 0,0158 & 0,0229 & 0,0141 & 0,0169 & 0,0195 & 0,0240 & 0,0265 & 0,0089 & 0,0055 & 0,0094 \\
\hline Log Income & 0,0221 & 0,0214 & 0,0154 & 0,0207 & 0,0246 & 0,0209 & 0,0220 & 0,0198 & 0,0206 & 0,0204 & 0,0206 & 0,0209 & 0,0215 & 0,0204 & 0,0185 & 0,0190 & 0,0207 \\
\hline F20-24 & 0,0345 & 0,0206 & 0,2271 & 0,0721 & 0,0672 & 0,2351 & $-0,2074$ & $-0,0163$ & 0,1535 & 0,1389 & 0,0292 & $-0,0062$ & 0,1448 & 0,2358 & 0,1512 & $-0,0141$ & 0,0993 \\
\hline F25-29 & 0,0330 & 0,3779 & 0,1314 & 0,3521 & 0,0557 & 0,0628 & 0,3388 & 0,0632 & 0,1805 & 0,2001 & 0,1780 & 0,1308 & 0,1527 & 0,0720 & 0,4246 & 0,3843 & 0,1843 \\
\hline F30-34 & 0,0662 & 0,1999 & 0,0548 & 0,1646 & 0,0744 & 0,0689 & 0,0612 & 0,1219 & 0,1922 & 0,0460 & 0,1315 & 0,1982 & 0,1959 & 0,0699 & 0,1631 & 0,1183 & 0,1387 \\
\hline F35-39 & 0,0625 & 0,1308 & 0,0259 & $-0,0756$ & 0,1094 & $-0,1247$ & 0,0689 & 0,0323 & 0,1169 & 0,0738 & $-0,0667$ & $-0,0694$ & $-0,1304$ & 0,0928 & 0,2670 & 0,2109 & 0,1750 \\
\hline F45-49 & $-0,1119$ & 0,0156 & $-0,0903$ & 0,1256 & $-0,0009$ & $-0,0351$ & $-0,1030$ & $-0,0195$ & $-0,0461$ & 0,0471 & 0,1429 & 0,0357 & 0,0033 & $-0,2123$ & 0,0793 & $-0,0587$ & 0,2404 \\
\hline F50-54 & 0,0298 & 0,0070 & 0,1588 & $-0,1117$ & $-0,0493$ & 0,0943 & $-0,0101$ & $-0,0492$ & 0,0199 & $-0,1124$ & 0,1235 & $-0,1090$ & $-0,0810$ & 0,1077 & $-0,1052$ & $-0,1280$ & 0,0227 \\
\hline F55-59 & $-0,1398$ & $-0,1231$ & 0,0294 & $-0,0268$ & 0,0524 & $-0,1412$ & $-0,0592$ & $-0,0667$ & $-0,2045$ & $-0,0880$ & 0,0575 & $-0,0506$ & $-0,1451$ & $-0,0796$ & $-0,0526$ & 0,0034 & $-0,0909$ \\
\hline F60-64 & $-0,3327$ & $-0,3877$ & 0,0296 & $-0,2158$ & $-0,3927$ & $-0,3813$ & $-0,0476$ & $-0,1557$ & $-0,1300$ & $-0,3110$ & $-0,2414$ & $-0,1546$ & $-0,1029$ & 0,0219 & $-0,4274$ & $-0,4987$ & $-0,1887$ \\
\hline F65-69 & $-0,1038$ & $-0,2648$ & $-0,1794$ & $-0,3060$ & $-0,4182$ & $-0,1665$ & $-0,4324$ & $-0,3410$ & $-0,3132$ & $-0,2610$ & $-0,1304$ & $-0,0982$ & $-0,3731$ & $-0,2601$ & $-0,2733$ & $-0,2559$ & $-0,4938$ \\
\hline F70-74 & $-0,0853$ & $-0,3605$ & $-0,2006$ & $-0,3591$ & $-0,1627$ & $-0,1614$ & $-0,3276$ & $-0,2500$ & $-0,3855$ & $-0,4201$ & $-0,1435$ & $-0,2235$ & $-0,4124$ & $-0,3192$ & $-0,4442$ & $-0,4738$ & $-0,3163$ \\
\hline F75-79 & $-0,2143$ & $-0,4778$ & $-0,5556$ & $-0,3502$ & $-0,1137$ & $-0,2346$ & $-0,3571$ & $-0,3997$ & $-0,4573$ & $-0,2189$ & $-0,0933$ & $-0,1809$ & $-0,4030$ & $-0,2137$ & $-0,4094$ & $-0,1479$ & $-0,1794$ \\
\hline M16-19 & 0,0114 & 0,1356 & $-0,1255$ & 0,0529 & 0,0960 & 0,0350 & 0,0188 & $-0,0031$ & 0,2436 & 0,0814 & 0,0043 & $-0,1071$ & $-0,1168$ & 0,0855 & 0,2202 & $-0,1647$ & $-0,0035$ \\
\hline M20-24 & 0,1647 & 0,1470 & 0,1258 & 0,2195 & 0,1562 & 0,2216 & 0,2017 & 0,2443 & 0,1598 & 0,2979 & 0,1953 & 0,2322 & 0,2119 & 0,1047 & 0,2486 & 0,0449 & 0,2140 \\
\hline M25-29 & 0,1712 & 0,3172 & 0,2932 & 0,0875 & 0,1778 & 0,2963 & 0,2483 & 0,3521 & 0,2417 & 0,2329 & 0,3553 & 0,2616 & 0,1805 & 0,1042 & 0,3608 & 0,2439 & 0,2524 \\
\hline M30-34 & 0,1510 & 0,1499 & 0,2000 & 0,2373 & 0,1855 & 0,3478 & 0,4368 & 0,3462 & 0,4064 & 0,2400 & 0,1798 & 0,1262 & 0,2282 & 0,2826 & 0,3536 & 0,2268 & 0,2637 \\
\hline M35-39 & 0,1143 & 0,2096 & 0,1410 & 0,2121 & 0,1053 & 0,1520 & 0,2404 & 0,1707 & 0,0693 & 0,0746 & 0,1858 & 0,0892 & 0,0869 & $-0,0382$ & $-0,0063$ & 0,3330 & 0,2167 \\
\hline M40-44 & 0,1029 & 0,2918 & $-0,0044$ & $-0,0382$ & $-0,0052$ & 0,0289 & 0,2783 & 0,0922 & 0,1779 & 0,0029 & 0,1944 & 0,0827 & 0,0664 & 0,3414 & 0,3277 & 0,0389 & 0,1361 \\
\hline M45-49 & $-0,0306$ & 0,1946 & $-0,0260$ & 0,0458 & 0,0161 & 0,1089 & 0,3237 & 0,1535 & 0,2294 & 0,0369 & $-0,1039$ & 0,0617 & 0,1378 & $-0,0338$ & 0,2496 & 0,0430 & 0,1590 \\
\hline M50-54 & 0,0797 & 0,1806 & 0,0990 & 0,2186 & $-0,0163$ & $-0,0938$ & $-0,0706$ & 0,2599 & $-0,0615$ & $-0,0455$ & 0,0008 & 0,2131 & 0,0091 & $-0,0666$ & $-0,1879$ & $-0,0073$ & 0,1892 \\
\hline M55-59 & $-0,0465$ & 0,1018 & 0,2679 & 0,1546 & $-0,0289$ & 0,2344 & 0,0207 & 0,2414 & $-0,1715$ & 0,1389 & 0,0811 & $-0,0422$ & 0,1514 & $-0,2178$ & $-0,3036$ & 0,2017 & $-0,1162$ \\
\hline M60-64 & $-0,0658$ & $-0,1490$ & 0,0224 & $-0,1784$ & 0,0480 & $-0,0846$ & 0,0088 & $-0,0487$ & 0,0771 & 0,0427 & $-0,1892$ & $-0,1629$ & $-0,0361$ & $-0,1007$ & 0,0323 & $-0,1161$ & $-0,0265$ \\
\hline M65-69 & $-0,2158$ & $-0,2339$ & $-0,0289$ & $-0,4126$ & $-0,1985$ & $-0,3639$ & $-0,2693$ & $-0,1717$ & $-0,1941$ & $-0,1471$ & $-0,3566$ & $-0,3075$ & $-0,0705$ & $-0,4091$ & $-0,1619$ & $-0,2608$ & $-0,1829$ \\
\hline M70-74 & $-0,2456$ & $-0,4289$ & $-0,2280$ & $-0,4077$ & $-0,3691$ & $-0,2988$ & $-0,3407$ & $-0,2035$ & $-0,1910$ & $-0,2507$ & $-0,3484$ & $-0,2165$ & $-0,3347$ & $-0,2884$ & $-0,3245$ & $-0,0933$ & $-0,4337$ \\
\hline M75-79 & $-0,2326$ & $-0,3879$ & $-0,2723$ & $-0,3689$ & $-0,2368$ & $-0,1569$ & $-0,2895$ & $-0,1267$ & $-0,3711$ & $-0,0969$ & $-0,2860$ & $-0,2411$ & $-0,0389$ & $-0,3670$ & $-0,3926$ & $-0,1965$ & $-0,3414$ \\
\hline
\end{tabular}




\begin{tabular}{|c|c|c|c|c|c|c|c|c|c|c|c|c|c|c|c|c|c|}
\hline & Andalucía & Aragón & Asturias & Baleares & Canarias & Cantabria & $\begin{array}{l}\text { Castilla La } \\
\text { Mancha }\end{array}$ & $\begin{array}{l}\text { Castilla } \\
\text { León }\end{array}$ & Catalonia & Valencia & Extremadure & Galicia & Madrid & Murcia & Navarra & $\begin{array}{c}\text { Pasís } \\
\text { Vasco }\end{array}$ & La Rioja \\
\hline M80 & $-0,0339$ & $-0,4291$ & 0,0305 & $-0,4558$ & $-0,1455$ & $-0,0624$ & $-0,2416$ & $-0,4205$ & $-0,6055$ & $-0,0164$ & $-0,4035$ & $-0,2212$ & $-0,0157$ & $-0,2667$ & $-0,5007$ & $-0,6008$ & $-0,1782$ \\
\hline Illiterate & $-0,4572$ & $-0,0883$ & $-0,5410$ & $-0,4751$ & $-0,4298$ & $-0,8123$ & $-0,4627$ & $-0,8377$ & $-0,5089$ & $-0,3794$ & $-0,4088$ & $-0,8233$ & $-0,6401$ & $-0,4256$ & $-0,0827$ & $-0,5104$ & $-0,1397$ \\
\hline $\begin{array}{l}\text { Primary } \\
\text { School }\end{array}$ & $-0,1588$ & $-0,2630$ & $-0,1673$ & $-0,2555$ & $-0,2481$ & $-0,2144$ & $-0,1858$ & $-0,1710$ & $-0,2647$ & $-0,1813$ & $-0,0633$ & $-0,1883$ & $-0,2839$ & $-0,1967$ & $-0,2765$ & $-0,2291$ & $-0,2363$ \\
\hline $\begin{array}{l}\text { Secondary } \\
\text { School }\end{array}$ & 0,0722 & 0,1703 & 0,0697 & 0,0539 & 0,0523 & 0,0762 & 0,1422 & 0,1089 & 0,1035 & 0,1180 & 0,0984 & 0,0807 & 0,0250 & 0,1196 & 0,1488 & 0,0803 & 0,1032 \\
\hline $\begin{array}{c}\text { Divorced / } \\
\text { Separated }\end{array}$ & $-0,0430$ & 0,0978 & $-0,2552$ & 0,2235 & $-0,0186$ & $-0,1347$ & 0,2161 & 0,1497 & 0,0316 & $-0,1470$ & 0,2265 & 0,0360 & $-0,0023$ & 0,0254 & $-0,1294$ & 0,0729 & 0,0644 \\
\hline Widow & $-0,0575$ & $-0,3130$ & $-0,4002$ & $-0,3507$ & $-0,2007$ & $-0,2449$ & $-0,1423$ & $-0,2289$ & $-0,3658$ & $-0,2280$ & $-0,0586$ & $-0,2119$ & $-0,2548$ & $-0,1942$ & $-0,2769$ & $-0,2579$ & $-0,2020$ \\
\hline Employed & 0,2430 & 0,2627 & 0,1551 & 0,1998 & 0,1931 & 0,2046 & 0,3017 & 0,2535 & 0,1939 & 0,2196 & 0,2125 & 0,1963 & 0,1898 & 0,1575 & 0,2609 & 0,2261 & 0,2332 \\
\hline Pensioner & $-0,1993$ & $-0,3035$ & $-0,1666$ & $-0,3329$ & $-0,1973$ & $-0,2477$ & $-0,2469$ & $-0,1887$ & $-0,2706$ & $-0,1803$ & $-0,2144$ & $-0,2470$ & $-0,1992$ & $-0,2775$ & $-0,3067$ & $-0,2189$ & $-0,2832$ \\
\hline Unemployed & $-0,2247$ & $-0,2619$ & $-0,1817$ & $-0,0762$ & $-0,3063$ & $-0,3758$ & $-0,2091$ & $-0,0459$ & $-0,0745$ & $-0,2578$ & $-0,0994$ & $-0,1475$ & $-0,1831$ & $-0,2972$ & $-0,1631$ & $-0,2383$ & $-0,0755$ \\
\hline Student & 0,0804 & 0,2528 & 0,1122 & 0,1319 & 0,0725 & 0,1452 & 0,0066 & 0,0534 & 0,1691 & 0,1163 & 0,0939 & 0,1297 & 0,0449 & 0,2731 & 0,2073 & $-0,0955$ & $-0,0708$ \\
\hline
\end{tabular}


Table 3: Health inequality contributions of regressors per region.

\begin{tabular}{|c|c|c|c|c|c|c|c|c|c|c|c|c|c|c|c|c|c|}
\hline & Andalucía & Aragón & sturias & Baleares & Canarias & Cantabria & $\begin{array}{c}\text { CastillaLa } \\
\text { Mancha }\end{array}$ & $\begin{array}{l}\text { Castilla } \\
\text { León }\end{array}$ & Catalonia & Valencia & Extremadurc & Galicia & Madrid & Murcia & Navarra & País Vasco & La Rioja \\
\hline $\begin{array}{c}\text { C HUI } \\
\text { predicted }\end{array}$ & 0,01924 & 0,01812 & 0,01423 & 0,02355 & 0,02095 & 0,01435 & 0,01710 & 0,01582 & 0,02294 & 0,01414 & 0,01689 & 0,01947 & 0,02402 & 0,02651 & 0,00888 & 0,00546 & 0,00944 \\
\hline $\mathrm{I}^{*}=\mathrm{C}-\mathrm{C}^{*}$ & 0,01600 & 000971 & 0,01026 & 0,02408 & 0,01691 & 001230 & 0,01079 & 0,00716 & 0,01951 & 0,00945 & 0,01447 & 0,01538 & 01822 & 02326 & 42 & 0,00416 & 0333 \\
\hline$\underset{\text { Income }}{\log }$ & 0,01157 & 0,00238 & 0,00583 & 0,01626 & 0,00571 & 0,00163 & 0,00465 & 0,00411 & 0,01066 & 0,00426 & 0, & 16 & 0,01603 & 0,01036 & $-0,00128$ & 40 & 00132 \\
\hline As \% & $60,12 \%$ & $13,16 \%$ & $40,93 \%$ & $69,05 \%$ & $27,25 \%$ & $11,37 \%$ & $27,21 \%$ & $25,98 \%$ & $46,46 \%$ & $30,15 \%$ & $19,57 \%$ & $47,05 \%$ & $66,75 \%$ & $39,08 \%$ & $-14,39 \%$ & $7,27 \%$ & $13,99 \%$ \\
\hline F20-24 & $-0,00004$ & 0,00001 & $-0,00013$ & 0,00008 & 0,00001 & $-0,00027$ & 0,00018 & 0,00000 & $-0,00005$ & $-0,00007$ & 0,00001 & $-0,00001$ & $-0,00018$ & 0,00000 & $-0,00048$ & 0,00001 & 0,00004 \\
\hline F25-29 & $-0,00002$ & $-0,00005$ & $-0,00021$ & $-0,00061$ & 0,00013 & $-0,00004$ & 20 & $-0,00003$ & $-0,00029$ & $-0,00014$ & 37 & 0007 & $-0,00007$ & 0004 & 005 & 028 & 0006 \\
\hline F30-34 & $-0,00009$ & 0,00015 & $-0,00011$ & $-0,00010$ & 0,00016 & $-0,00002$ & $-0,00003$ & $-0,00003$ & $-0,00021$ & $-0,00003$ & 0,00023 & 0,00002 & $-0,00012$ & 0,00006 & $-0,00040$ & 0,00002 & 0,00011 \\
\hline F35-39 & $-0,00016$ & $-0,00019$ & $-0,00004$ & 0,00005 & 0,00017 & 0,00040 & 0,00003 & $-0,00005$ & $-0,00024$ & $-0,00002$ & $-0,00014$ & $-0,00004$ & 0,00032 & 0,00001 & 0,00001 & $-0,00023$ & $-0,00021$ \\
\hline F40-44 & $-0,00047$ & 0,00002 & 0,00013 & $-0,00036$ & $-0,00011$ & $-0,00022$ & 0,00004 & $-0,00009$ & $-0,00005$ & 0,00013 & 0,00000 & $-0,00004$ & $-0,00005$ & 0,00022 & $-0,00020$ & $-0,00019$ & 0,00000 \\
\hline F45-49 & 0,00027 & $-0,00003$ & 0,00017 & $-0,00032$ & 0,00000 & 0,00004 & 0,00013 & 0,00001 & 0,00009 & $-0,00007$ & 0,00006 & $-0,00003$ & $-0,00001$ & 0,00027 & $-0,00023$ & 0,00012 & $-0,00016$ \\
\hline F50-54 & $-0,00008$ & $-0,00001$ & $-0,00065$ & 0,00027 & 0,00006 & $-0,00030$ & 0,00000 & 0,00008 & $-0,00008$ & 0,00023 & $-0,00032$ & 0,00008 & 0,00027 & $-0,00028$ & 0,00028 & 0,00018 & $-0,00003$ \\
\hline F55-59 & 0,00076 & 0,00020 & $-0,00010$ & 0,00003 & $-0,00016$ & 0,00059 & 0,00020 & 0,00010 & 0,00099 & 0,00013 & $-0,00001$ & 0,00009 & 0,00020 & 0,00025 & 0,00006 & $-0,00001$ & 0,00008 \\
\hline F60-64 & 0,00165 & 0,00080 & $-0,00004$ & $-0,00006$ & 0,00053 & 0,00108 & 0,00013 & 0,00041 & 0,00026 & 0,00103 & 0,00083 & 0,00035 & 0,00034 & 0,00000 & 0,00096 & 0,00049 & 0,00031 \\
\hline F65-69 & 0,00047 & 0,00067 & 0,00064 & 0,00091 & 0,00104 & 0,00082 & 0,00146 & 0,00230 & 0,00026 & 0,00081 & 0,00032 & 0,00037 & 0,00139 & $-0,00033$ & 0,00094 & 0,00003 & 0,00143 \\
\hline F70-74 & 0,00048 & 0,00214 & 0,00072 & 0,00074 & $-0,00006$ & 0,00050 & 0,00187 & 0,00233 & 0,00121 & 0,00161 & 0,00039 & 0,00042 & 0,00201 & 0,00006 & 0,00217 & 0,00187 & 0,00072 \\
\hline F75-79 & 0,00029 & 0,00072 & 0,00330 & 0,00034 & 0,00019 & 0,00039 & 0,00075 & 0,00143 & 0,00152 & 0,00065 & 0,00021 & 0,00067 & 0,00104 & 0,00071 & 0,00073 & 0,00022 & 0,00061 \\
\hline F80 & $-0,00013$ & 0,00139 & 0,00089 & 0,00030 & 0,00004 & 0,00087 & 0,00129 & 0,00087 & 0,00089 & 0,00045 & 0,00022 & 0,00072 & 0,00079 & 0,00040 & 0,00078 & 0,00032 & 0,00087 \\
\hline M16-19 & 0,00000 & $-0,00004$ & $-0,00001$ & 0,00009 & 0,00009 & $-0,00004$ & 0,00000 & 0,00000 & $-0,00003$ & $-0,00003$ & 0,00000 & $-0,00010$ & 0,00008 & $-0,00001$ & $-0,00004$ & 0,00004 & 0,00000 \\
\hline M20-24 & $-0,00002$ & $-0,00003$ & $-0,00006$ & 0,00014 & 0,00052 & $-0,00027$ & $-0,00001$ & 0,00002 & 0,00001 & $-0,00032$ & 0,00014 & $-0,00005$ & 0,00011 & 0,00014 & 0,00001 & 0,00000 & 0,00007 \\
\hline M25-29 & $-0,00017$ & $-0,00013$ & $-0,00018$ & 0,00018 & 0,00019 & $-0,00009$ & 0,00006 & $-0,00003$ & $-0,00022$ & $-0,00012$ & 0,00037 & 0,00022 & 0,00001 & 0,00009 & $-0,00026$ & 0,00015 & 0,00026 \\
\hline M30-34 & $-0,00016$ & $-0,00007$ & $-0,00049$ & 0,00020 & 0,00048 & $-0,00013$ & 0,00001 & $-0,00018$ & $-0,00050$ & $-0,00033$ & 0,00033 & $-0,00001$ & $-0,00019$ & 0,00044 & $-0,00048$ & $-0,00029$ & 0,00018 \\
\hline M35-39 & $-0,00031$ & $-0,00008$ & $-0,00020$ & $-0,00023$ & 0,00010 & $-0,00007$ & 0,00004 & $-0,00012$ & $-0,00005$ & $-0,00007$ & 0,00022 & $-0,00014$ & $-0,00012$ & $-0,00008$ & 0,00000 & $-0,00090$ & 0,00023 \\
\hline M40-44 & $-0,00012$ & $-0,00050$ & 0,00000 & $-0,00004$ & 0,00000 & $-0,00007$ & 0,00012 & 0,00003 & $-0,00035$ & 0,00000 & 0,00023 & $-0,00003$ & $-0,00003$ & 0,00057 & $-0,00047$ & $-0,00006$ & 0,00005 \\
\hline M45-49 & 0,00005 & $-0,00019$ & 0,00013 & $-0,00009$ & $-0,00002$ & $-0,00016$ & 0,00004 & $-0,00021$ & $-0,00040$ & $-0,00004$ & $-0,00013$ & 0,00000 & $-0,00039$ & $-0,00006$ & $-0,00005$ & $-0,00002$ & 0,00003 \\
\hline M50-54 & $-0,00022$ & 0,00006 & $-0,00030$ & $-0,00025$ & $-0,00001$ & 0,00000 & 0,00009 & $-0,00027$ & 0,00007 & 0,00016 & 0,00000 & $-0,00020$ & $-0,00001$ & $-0,00002$ & 0,00050 & 0,00002 & $-0,00020$ \\
\hline
\end{tabular}




\begin{tabular}{|c|c|c|c|c|c|c|c|c|c|c|c|c|c|c|c|c|c|}
\hline M55-59 & 0,00005 & $-0,00009$ & $-0,00108$ & $-0,00028$ & 0,00000 & 0,00026 & $-0,00001$ & $-0,00034$ & 0,00026 & $-0,00035$ & 0,00009 & 0,00007 & $-0,00019$ & $-0,00012$ & 0,00117 & $-0,00046$ & 0,00009 \\
\hline M60-64 & 0,00015 & 0,00019 & $-0,00005$ & $-0,00019$ & 0,00007 & 0,00007 & 0,00000 & 0,00010 & 0,00001 & $-0,00010$ & 0,00009 & 0,00008 & 0,00006 & 0,00023 & $-0,00001$ & $-0,00020$ & 0,00002 \\
\hline M65-69 & 0,00005 & 0,00075 & 0,00010 & $-0,00043$ & 0,00025 & $-0,00079$ & $-0,00024$ & 0,00010 & 0,00021 & 0,00030 & $-0,00109$ & $-0,00006$ & 0,00017 & 0,00009 & 0,00034 & 0,00017 & $-0,00006$ \\
\hline M70-74 & 0,00082 & 0,00025 & 0,00059 & $-0,00040$ & 0,00039 & $-0,00038$ & $-0,00016$ & 0,00086 & 0,00002 & 0,00053 & $-0,00053$ & 0,00076 & 0,00030 & 0,00016 & 0,00053 & 0,00004 & 0,00086 \\
\hline M75-79 & 0,00017 & 0,00105 & 0,00096 & 0,00008 & $-0,00028$ & $-0,00008$ & 0,00036 & 0,00030 & $-0,00023$ & 0,00031 & $-0,00008$ & 0,00045 & 0,00004 & 0,00003 & 0,00061 & $-0,00013$ & 0,00019 \\
\hline M80 & 0,00002 & 0,00142 & $-0,00002$ & $-0,00058$ & 0,00027 & 0,00002 & $-0,00026$ & 0,00108 & 0,00032 & 0,00002 & 0,00060 & 0,00041 & 0,00002 & 0,00040 & 0,00106 & $-0,00018$ & 0,00057 \\
\hline As $\%$ & $16,85 \%$ & $46,43 \%$ & $27,96 \%$ & $-2,24 \%$ & $19,28 \%$ & $14,30 \%$ & $36,87 \%$ & $54,73 \%$ & $14,95 \%$ & $33,16 \%$ & $14,36 \%$ & $20,99 \%$ & $24,12 \%$ & $12,26 \%$ & $83,98 \%$ & $23,81 \%$ & $64,70 \%$ \\
\hline Illiterate & 0,00078 & 0,00025 & $-0,00014$ & 0,00055 & 0,00198 & 0,00083 & 0,00001 & 0,00026 & 0,00127 & 0,00065 & 0,00313 & 0,00027 & 0,00069 & 0,00288 & 0,00000 & 0,00000 & 0,00004 \\
\hline $\begin{array}{l}\text { Primary } \\
\text { school }\end{array}$ & $-0,00098$ & 0,00175 & $-0,00018$ & $-0,00129$ & 0,00165 & 0,00076 & $-0,00085$ & 0,00123 & 0,00122 & $-0,00066$ & $-0,00007$ & 0,00054 & $-0,00120$ & $-0,00069$ & 0,00015 & $-0,00095$ & 0,00154 \\
\hline $\begin{array}{c}\text { Secondary } \\
\text { School }\end{array}$ & 0,00115 & $-0,00023$ & 0,00064 & 0,00166 & 0,00007 & 0,00081 & 0,00050 & $-0,00097$ & $-0,00004$ & 0,00061 & 0,00077 & 0,00026 & 0,00019 & 0,00116 & $-0,00073$ & $-0,00015$ & $-0,00027$ \\
\hline As \% & $5,78 \%$ & $14,16 \%$ & $2,37 \%$ & $1,68 \%$ & $30,86 \%$ & $14,23 \%$ & $3,54 \%$ & $4,54 \%$ & $15,48 \%$ & $14,55 \%$ & $26,67 \%$ & $14,20 \%$ & $-2,59 \%$ & $18,57 \%$ & $-1,70 \%$ & $-27,14 \%$ & $20,97 \%$ \\
\hline Married & $-0,00019$ & 0,00002 & $-0,00018$ & $-0,00061$ & 0,00000 & 0,00033 & 0,00006 & $-0,00018$ & $-0,00001$ & $-0,00004$ & 0,00012 & $-0,00017$ & $-0,00077$ & 0,00027 & $-0,00007$ & $-0,00016$ & 0,00000 \\
\hline $\begin{array}{r}\text { Divorced / } \\
\text { Separated }\end{array}$ & 0,000 & $-0,00022$ & 0 & $-0,00002$ & 0 & 0 & 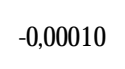 & -( & 0 & 0,00019 & $-c$ & 0,00000 & 0 & 5 & 3 & 12 & 02 \\
\hline Widow & $-0,00006$ & $-0,00033$ & 0,00265 & $-0,00199$ & $-0,00031$ & 0,00086 & 0,00012 & $-0,00042$ & $-0,00095$ & 0,00020 & $-0,00054$ & $-0,00066$ & $-0,00015$ & 0,00016 & 0,00010 & $-0,00060$ & $-0,00106$ \\
\hline Employed & 0,00130 & 0,00358 & 0,00149 & 0,00373 & 0,00195 & 0,00065 & 0,00083 & 0,00137 & 0,00106 & 0,00319 & 0,00267 & 0,00298 & 0,00434 & 0,00117 & 0,00094 & 0,00434 & $-0,00132$ \\
\hline Pensioner & 0,00226 & 0,00106 & 0,00006 & 0,00638 & 0,00131 & 0,00541 & 0,00456 & 0,00161 & 0,00491 & $-0,00014$ & 0,00482 & 0,00107 & $-0,00031$ & 0,00600 & 0,00123 & 0,00253 & 0,00230 \\
\hline Unemployed & $-0,00006$ & 0,00008 & $-0,00026$ & $-0,00018$ & 0,00155 & 0,00098 & 0,00005 & 0,00003 & 0,00005 & $-0,00064$ & $-0,00023$ & $-0,00006$ & $-0,00049$ & $-0,00031$ & 0,00039 & $-0,00040$ & 0,00013 \\
\hline Student & 0,00003 & 0,00058 & $-0,00005$ & 0,00011 & 0,00021 & $-0,00004$ & 0,00001 & 0,00005 & 0,00022 & 0,00038 & 0,00028 & 0,00030 & 0,00021 & 0,00074 & 0,00028 & $-0,00035$ & $-0,00001$ \\
\hline As \% & $18,34 \%$ & $29,20 \%$ & $8,70 \%$ & $42,63 \%$ & $23,95 \%$ & $48,76 \%$ & $31,90 \%$ & $19,42 \%$ & $27,20 \%$ & $19,73 \%$ & $44,58 \%$ & $21,99 \%$ & $15,57 \%$ & $28,65 \%$ & $32,11 \%$ & $112,10 \%$ & $11,72 \%$ \\
\hline
\end{tabular}


Table 4: Contributions of regressors to excess health inequalities per region versus País Vasco (in \% of excess concentration index of HUI in first row)

\begin{tabular}{|c|c|c|c|c|c|c|c|c|c|c|c|c|c|c|c|c|}
\hline & Andalucía & Aragón & Asturias & Baleares & Canarias & Cantabria & $\begin{array}{c}\text { Castilla La } \\
\text { Mancha }\end{array}$ & $\begin{array}{l}\text { Castilla } \\
\text { León }\end{array}$ & Catalonia & Valencia & Extremadura & Galicia & Madrid & Murcia & Navarra & La Rioja \\
\hline $\begin{array}{c}\text { Excess } \\
\text { inequality } \\
\text { CI-CIPV }\end{array}$ & $252,4 \%$ & $231,9 \%$ & $160,7 \%$ & $331,3 \%$ & $283,7 \%$ & $162,8 \%$ & $213,1 \%$ & $189,7 \%$ & $320,1 \%$ & $159,0 \%$ & $209,4 \%$ & $256,6 \%$ & $339,8 \%$ & $385,5 \%$ & $62,6 \%$ & $72,8 \%$ \\
\hline Log Income & $81,0 \%$ & $15,7 \%$ & $61,9 \%$ & $87,7 \%$ & $34,3 \%$ & $13,9 \%$ & $36,6 \%$ & $35,8 \%$ & $58,7 \%$ & $44,5 \%$ & $25,4 \%$ & $62,6 \%$ & $84,2 \%$ & $47,3 \%$ & $-49,0 \%$ & $23,2 \%$ \\
\hline F20-24 & $-0,4 \%$ & $-0,1 \%$ & $-1,6 \%$ & $0,4 \%$ & $0,0 \%$ & $-3,2 \%$ & $1,4 \%$ & $-0,1 \%$ & $-0,4 \%$ & $-1,0 \%$ & $0,0 \%$ & $-0,1 \%$ & $-1,0 \%$ & $-0,1 \%$ & $-14,5 \%$ & $0,6 \%$ \\
\hline F25-29 & $-2,2 \%$ & $-2,6 \%$ & $-5,6 \%$ & $-4,9 \%$ & $-1,0 \%$ & $-3,6 \%$ & $-0,7 \%$ & $-3,0 \%$ & $-3,2 \%$ & $-4,8 \%$ & $0,8 \%$ & $-1,5 \%$ & $-1,9 \%$ & $-1,1 \%$ & $-9,7 \%$ & $-5,4 \%$ \\
\hline F30-34 & $-0,8 \%$ & $1,0 \%$ & $-1,4 \%$ & $-0,6 \%$ & $0,9 \%$ & $-0,5 \%$ & $-0,4 \%$ & $-0,5 \%$ & $-1,3 \%$ & $-0,6 \%$ & $1,9 \%$ & $0,0 \%$ & $-0,8 \%$ & $0,2 \%$ & $-12,1 \%$ & $2,3 \%$ \\
\hline F35-39 & $0,5 \%$ & $0,4 \%$ & $2,2 \%$ & $1,6 \%$ & $2,6 \%$ & $7,1 \%$ & $2,2 \%$ & $1,7 \%$ & $-0,1 \%$ & $2,5 \%$ & $0,8 \%$ & $1,4 \%$ & $3,0 \%$ & $1,2 \%$ & $7,1 \%$ & $0,6 \%$ \\
\hline F40-44 & $-2,0 \%$ & $1,7 \%$ & $3,7 \%$ & $-0,9 \%$ & $0,5 \%$ & $-0,4 \%$ & $2,0 \%$ & $1,0 \%$ & $0,8 \%$ & $3,7 \%$ & $1,7 \%$ & $1,1 \%$ & $0,7 \%$ & $2,0 \%$ & $-0,4 \%$ & $4,8 \%$ \\
\hline F45-49 & $1,1 \%$ & $-1,2 \%$ & $0,6 \%$ & $-2,4 \%$ & $-0,8 \%$ & $-1,0 \%$ & $0,0 \%$ & $-1,1 \%$ & $-0,2 \%$ & $-2,2 \%$ & $-0,6 \%$ & $-1,1 \%$ & $-0,7 \%$ & $0,7 \%$ & $-10,2 \%$ & $-7,2 \%$ \\
\hline F50-54 & $-1,9 \%$ & $-1,5 \%$ & $-9,5 \%$ & $0,5 \%$ & $-0,8 \%$ & $-5,4 \%$ & $-1,6 \%$ & $-1,0 \%$ & $-1,5 \%$ & $0,6 \%$ & $-4,4 \%$ & $-0,7 \%$ & $0,5 \%$ & $-2,2 \%$ & $2,9 \%$ & $-5,5 \%$ \\
\hline F55-59 & $5,6 \%$ & $1,7 \%$ & $-1,0 \%$ & $0,2 \%$ & $-1,0 \%$ & $6,7 \%$ & $1,8 \%$ & $1,0 \%$ & $5,7 \%$ & $1,5 \%$ & $0,0 \%$ & $0,7 \%$ & $1,1 \%$ & $1,2 \%$ & $1,9 \%$ & $2,2 \%$ \\
\hline F60-64 & $8,4 \%$ & $2,4 \%$ & $-6,0 \%$ & $-3,1 \%$ & $0,3 \%$ & $6,5 \%$ & $-3,2 \%$ & $-0,8 \%$ & $-1,3 \%$ & $6,2 \%$ & $2,9 \%$ & $-1,1 \%$ & $-0,8 \%$ & $-2,3 \%$ & $13,7 \%$ & $-4,7 \%$ \\
\hline F65-69 & $3,2 \%$ & $5,0 \%$ & $6,9 \%$ & $4,8 \%$ & $6,5 \%$ & $8,8 \%$ & $12,3 \%$ & $21,8 \%$ & $1,3 \%$ & $9,0 \%$ & $2,5 \%$ & $2,4 \%$ & $7,3 \%$ & $-1,7 \%$ & $26,6 \%$ & $35,1 \%$ \\
\hline F70-74 & $-10,1 \%$ & $2,2 \%$ & $-13,1 \%$ & $-6,2 \%$ & $-12,4 \%$ & $-15,4 \%$ & $0,0 \%$ & $4,5 \%$ & $-3,8 \%$ & $-2,9 \%$ & $-13,0 \%$ & $-10,3 \%$ & $0,8 \%$ & $-8,6 \%$ & $8,9 \%$ & $-29,0 \%$ \\
\hline F75-79 & $0,5 \%$ & $4,0 \%$ & $35,1 \%$ & $0,7 \%$ & $-0,2 \%$ & $1,9 \%$ & $4,6 \%$ & $11,6 \%$ & $7,4 \%$ & $4,9 \%$ & $-0,1 \%$ & $3,2 \%$ & $4,4 \%$ & $2,3 \%$ & $14,9 \%$ & $9,9 \%$ \\
\hline F80 & $-3,3 \%$ & $8,4 \%$ & $6,5 \%$ & $-0,1 \%$ & $-1,8 \%$ & $6,2 \%$ & $8,4 \%$ & $5,3 \%$ & $3,3 \%$ & $1,5 \%$ & $-0,9 \%$ & $2,8 \%$ & $2,5 \%$ & $0,4 \%$ & $13,3 \%$ & $13,8 \%$ \\
\hline M16-19 & $-0,3 \%$ & $-0,6 \%$ & $-0,6 \%$ & $0,3 \%$ & $0,3 \%$ & $-0,9 \%$ & $-0,3 \%$ & $-0,4 \%$ & $-0,4 \%$ & $-0,8 \%$ & $-0,3 \%$ & $-1,0 \%$ & $0,2 \%$ & $-0,2 \%$ & $-2,4 \%$ & $-1,0 \%$ \\
\hline M20-24 & $-0,2 \%$ & $-0,3 \%$ & $-0,8 \%$ & $0,7 \%$ & $3,3 \%$ & $-3,1 \%$ & $-0,1 \%$ & $0,1 \%$ & $0,0 \%$ & $-3,7 \%$ & $1,2 \%$ & $-0,4 \%$ & $0,6 \%$ & $0,6 \%$ & $0,0 \%$ & $1,6 \%$ \\
\hline M25-29 & $-2,3 \%$ & $-2,2 \%$ & $-3,7 \%$ & $0,2 \%$ & $0,3 \%$ & $-2,7 \%$ & $-0,8 \%$ & $-1,7 \%$ & $-2,1 \%$ & $-3,0 \%$ & $1,9 \%$ & $0,5 \%$ & $-0,7 \%$ & $-0,3 \%$ & $-12,0 \%$ & $2,8 \%$ \\
\hline M30-34 & $0,9 \%$ & $1,7 \%$ & $-2,2 \%$ & $2,7 \%$ & $5,0 \%$ & $1,8 \%$ & $2,6 \%$ & $1,1 \%$ & $-1,2 \%$ & $-0,5 \%$ & $5,4 \%$ & $2,1 \%$ & $0,6 \%$ & $3,5 \%$ & $-5,6 \%$ & $11,8 \%$ \\
\hline M35-39 & $4,3 \%$ & $6,5 \%$ & $7,9 \%$ & $3,7 \%$ & $6,5 \%$ & $9,3 \%$ & $8,1 \%$ & $7,5 \%$ & $4,9 \%$ & $9,5 \%$ & $9,8 \%$ & $5,5 \%$ & $4,2 \%$ & $3,9 \%$ & $26,3 \%$ & $28,5 \%$ \\
\hline M40-44 & $-0,5 \%$ & $-3,5 \%$ & $0,7 \%$ & $0,1 \%$ & $0,4 \%$ & $-0,2 \%$ & $1,5 \%$ & $0,8 \%$ & $-1,6 \%$ & $0,7 \%$ & $2,6 \%$ & $0,2 \%$ & $0,1 \%$ & $3,0 \%$ & $-12,0 \%$ & $2,6 \%$ \\
\hline M45-49 & $0,5 \%$ & $-1,3 \%$ & $1,8 \%$ & $-0,4 \%$ & $0,0 \%$ & $-1,5 \%$ & $0,5 \%$ & $-1,8 \%$ & $-2,2 \%$ & $-0,2 \%$ & $-0,9 \%$ & $0,2 \%$ & $-2,0 \%$ & $-0,2 \%$ & $-0,9 \%$ & $1,4 \%$ \\
\hline M50-54 & $-1,7 \%$ & $0,3 \%$ & $-3,6 \%$ & $-1,5 \%$ & $-0,2 \%$ & $-0,3 \%$ & $0,6 \%$ & $-2,8 \%$ & $0,3 \%$ & $1,7 \%$ & $-0,2 \%$ & $-1,6 \%$ & $-0,1 \%$ & $-0,2 \%$ & $14,0 \%$ & $-5,6 \%$ \\
\hline M55-59 & $3,7 \%$ & $2,9 \%$ & $-7,1 \%$ & $1,0 \%$ & $3,0 \%$ & $8,1 \%$ & $3,9 \%$ & $1,2 \%$ & $4,1 \%$ & $1,3 \%$ & $4,8 \%$ & $3,8 \%$ & $1,4 \%$ & $1,6 \%$ & $47,7 \%$ & $13,9 \%$ \\
\hline M60-64 & $2,6 \%$ & $3,1 \%$ & $1,8 \%$ & $0,1 \%$ & $1,7 \%$ & $3,1 \%$ & $1,8 \%$ & $2,9 \%$ & $1,2 \%$ & $1,2 \%$ & $2,6 \%$ & $2,0 \%$ & $1,4 \%$ & $2,1 \%$ & $5,6 \%$ & $5,6 \%$ \\
\hline M65-69 & $-0,9 \%$ & $4,6 \%$ & $-0,8 \%$ & $-3,3 \%$ & $0,5 \%$ & $-10,8 \%$ & $-3,5 \%$ & $-0,6 \%$ & $0,2 \%$ & $1,5 \%$ & $-11,0 \%$ & $-1,6 \%$ & $0,0 \%$ & $-0,4 \%$ & $4,8 \%$ & $-5,7 \%$ \\
\hline M70-74 & $5,6 \%$ & $1,7 \%$ & $6,3 \%$ & $-2,5 \%$ & $2,2 \%$ & $-4,7 \%$ & $-1,8 \%$ & $7,8 \%$ & $-0,1 \%$ & $5,6 \%$ & $-5,0 \%$ & $5,1 \%$ & $1,4 \%$ & $0,5 \%$ & $14,3 \%$ & $20,6 \%$ \\
\hline
\end{tabular}




\begin{tabular}{|c|c|c|c|c|c|c|c|c|c|c|c|c|c|c|c|c|}
\hline M75-79 & $2,2 \%$ & $9,3 \%$ & $12,4 \%$ & $1,2 \%$ & $-1,0 \%$ & $0,5 \%$ & $4,2 \%$ & $4,1 \%$ & $-0,6 \%$ & $5,0 \%$ & $0,5 \%$ & $4,1 \%$ & $0,9 \%$ & $0,7 \%$ & $21,6 \%$ & $7,9 \%$ \\
\hline M80 & $1,5 \%$ & $12,6 \%$ & $1,9 \%$ & $-2,2 \%$ & $3,0 \%$ & $2,3 \%$ & $-0,6 \%$ & $12,2 \%$ & $2,9 \%$ & $2,4 \%$ & $6,9 \%$ & $4,3 \%$ & $1,1 \%$ & $2,8 \%$ & $36,5 \%$ & $18,9 \%$ \\
\hline Demographics & $14,1 \%$ & $56,2 \%$ & $30,5 \%$ & $-10,1 \%$ & $17,7 \%$ & $8,5 \%$ & $43,0 \%$ & $71,0 \%$ & $12,2 \%$ & $39,0 \%$ & $9,8 \%$ & $19,9 \%$ & $24,2 \%$ & $9,3 \%$ & $180,1 \%$ & $120,9 \%$ \\
\hline Illiterate & $5,6 \%$ & $1,9 \%$ & $-1,6 \%$ & $3,0 \%$ & $12,8 \%$ & $9,3 \%$ & $0,0 \%$ & $2,5 \%$ & $7,3 \%$ & $7,4 \%$ & $27,4 \%$ & $1,9 \%$ & $3,7 \%$ & $13,7 \%$ & $-0,1 \%$ & $1,0 \%$ \\
\hline $\begin{array}{l}\text { Reads and } \\
\text { writes }\end{array}$ & $4,0 \%$ & $9,3 \%$ & $4,6 \%$ & $-0,7 \%$ & $20,4 \%$ & $0,5 \%$ & $11,5 \%$ & $5,6 \%$ & $8,5 \%$ & $21,3 \%$ & $9,3 \%$ & $14,9 \%$ & $0,5 \%$ & $9,3 \%$ & $23,9 \%$ & $26,4 \%$ \\
\hline Primary School & $-0,2 \%$ & $21,3 \%$ & $8,8 \%$ & $-1,9 \%$ & $16,8 \%$ & $19,2 \%$ & $0,9 \%$ & $21,1 \%$ & $12,4 \%$ & $3,3 \%$ & $7,7 \%$ & $10,6 \%$ & $-1,4 \%$ & $1,2 \%$ & $32,1 \%$ & $62,7 \%$ \\
\hline $\begin{array}{l}\text { Secondary } \\
\text { School }\end{array}$ & $9,4 \%$ & $-0,7 \%$ & $9,0 \%$ & $10,0 \%$ & $1,4 \%$ & $10,7 \%$ & $5,6 \%$ & $-7,9 \%$ & $0,6 \%$ & $8,7 \%$ & $8,0 \%$ & $2,9 \%$ & $1,8 \%$ & $6,2 \%$ & $-17,0 \%$ & $-3,1 \%$ \\
\hline Education & $18,8 \%$ & $32,0 \%$ & $20,7 \%$ & $10,4 \%$ & $51,3 \%$ & $39,6 \%$ & $17,9 \%$ & $21,2 \%$ & $28,8 \%$ & $40,8 \%$ & $52,4 \%$ & $30,3 \%$ & $4,6 \%$ & $30,4 \%$ & $38,9 \%$ & $87,0 \%$ \\
\hline Married & $-0,2 \%$ & $1,4 \%$ & $-0,2 \%$ & $-2,5 \%$ & $1,0 \%$ & $5,6 \%$ & $1,9 \%$ & $-0,2 \%$ & $0,9 \%$ & $1,4 \%$ & $2,5 \%$ & $0,0 \%$ & $-3,3 \%$ & $2,0 \%$ & $2,8 \%$ & $4,1 \%$ \\
\hline $\begin{array}{c}\text { Divorced / } \\
\text { Separated }\end{array}$ & $1,1 \%$ & $-0,8 \%$ & $5,7 \%$ & $0,6 \%$ & $1,0 \%$ & $6,3 \%$ & $0,2 \%$ & $-0,2 \%$ & $0,7 \%$ & $3,5 \%$ & $-3,0 \%$ & $0,8 \%$ & $0,6 \%$ & $0,3 \%$ & $2,5 \%$ & $2,5 \%$ \\
\hline Widow & $3,9 \%$ & $2,1 \%$ & $37,0 \%$ & $-7,7 \%$ & $1,8 \%$ & $16,3 \%$ & $6,1 \%$ & $1,7 \%$ & $-2,0 \%$ & $9,1 \%$ & $0,5 \%$ & $-0,4 \%$ & $2,4 \%$ & $3,6 \%$ & $20,3 \%$ & $-11,6 \%$ \\
\hline Marital Status & $4,8 \%$ & $2,7 \%$ & $42,5 \%$ & $-9,6 \%$ & $3,8 \%$ & $28,2 \%$ & $8,2 \%$ & $1,3 \%$ & $-0,4 \%$ & $14,0 \%$ & $0,0 \%$ & $0,4 \%$ & $-0,3 \%$ & $6,0 \%$ & $25,6 \%$ & $-5,0 \%$ \\
\hline Employed & $-22,1 \%$ & $-6,0 \%$ & $-32,6 \%$ & $-3,4 \%$ & $-15,4 \%$ & $-41,6 \%$ & $-30,2 \%$ & $-28,7 \%$ & $-18,8 \%$ & $-13,3 \%$ & $-14,7 \%$ & $-9,8 \%$ & $0,0 \%$ & $-15,1 \%$ & $-99,5 \%$ & $-142,4 \%$ \\
\hline Pensioner & $-1,9 \%$ & $-11,6 \%$ & $-28,1 \%$ & $21,3 \%$ & $-7,9 \%$ & $32,4 \%$ & $17,5 \%$ & $-8,8 \%$ & $13,6 \%$ & $-30,7 \%$ & $20,1 \%$ & $-10,4 \%$ & $-15,3 \%$ & $16,5 \%$ & $-37,9 \%$ & $-5,7 \%$ \\
\hline Unemployed & $2,5 \%$ & $3,8 \%$ & $1,6 \%$ & $1,2 \%$ & $12,6 \%$ & $15,6 \%$ & $3,9 \%$ & $4,2 \%$ & $2,6 \%$ & $-2,7 \%$ & $1,5 \%$ & $2,4 \%$ & $-0,5 \%$ & $0,4 \%$ & $23,3 \%$ & $13,5 \%$ \\
\hline Student & $2,8 \%$ & $7,3 \%$ & $3,5 \%$ & $2,5 \%$ & $3,6 \%$ & $3,4 \%$ & $3,1 \%$ & $3,9 \%$ & $3,2 \%$ & $8,4 \%$ & $5,5 \%$ & $4,6 \%$ & $3,0 \%$ & $5,2 \%$ & $18,5 \%$ & $8,5 \%$ \\
\hline Job status & $-18,8 \%$ & $-6,5 \%$ & $-55,6 \%$ & $21,7 \%$ & $-7,1 \%$ & $9,9 \%$ & $-5,7 \%$ & $-29,5 \%$ & $0,7 \%$ & $-38,4 \%$ & $12,3 \%$ & $-13,1 \%$ & $-12,8 \%$ & $7,0 \%$ & $-95,6 \%$ & $-126,1 \%$ \\
\hline
\end{tabular}


Table 5: Relative excess elasticity and inequality (vs País Vasco) of determinants per region

\begin{tabular}{|c|c|c|c|c|c|c|c|c|c|c|c|c|c|c|c|c|}
\hline & \multicolumn{2}{|c|}{ Andalucía } & \multicolumn{2}{|c|}{ Aragón } & \multicolumn{2}{|c|}{ Asturias } & \multicolumn{2}{|c|}{ Baleares } & \multicolumn{2}{|c|}{ Canarias } & \multicolumn{2}{|c|}{ Cantabria } & \multicolumn{2}{|c|}{ Castilla - La Mancha } & \multicolumn{2}{|c|}{ Castilla - León } \\
\hline & $\mathrm{CI}$ & Elasticity & CI & Elasticity & $\mathrm{CI}$ & Elasticity & $\mathrm{CI}$ & Elasticity & CI & Elasticity & CI & Elasticity & $\mathrm{CI}$ & Elasticity & CI & Elasticity \\
\hline Log Income & $16,0 \%$ & $2413,1 \%$ & $12,6 \%$ & $433,7 \%$ & $-18,9 \%$ & $1711,4 \%$ & $8,9 \%$ & $3663,8 \%$ & $29,5 \%$ & $1011,4 \%$ & $9,7 \%$ & $275,1 \%$ & $15,4 \%$ & $915,5 \%$ & $4,3 \%$ & $892,9 \%$ \\
\hline F20-24 & $-344,2 \%$ & $22,4 \%$ & $-245,9 \%$ & $-132,3 \%$ & $-1707,6 \%$ & $-45,8 \%$ & $-610,7 \%$ & $-207,5 \%$ & $-575,8 \%$ & $-113,7 \%$ & $-1763,8 \%$ & $13,7 \%$ & $1368,3 \%$ & $-16,0 \%$ & $15,2 \%$ & $-96,0 \%$ \\
\hline F25-29 & $-91,4 \%$ & $-178,0 \%$ & $-1,7 \%$ & $-117,4 \%$ & $-65,8 \%$ & $-323,2 \%$ & $-8,4 \%$ & $-340,0 \%$ & $-85,5 \%$ & $210,6 \%$ & $-83,6 \%$ & $-187,9 \%$ & $-11,8 \%$ & $-20,0 \%$ & $-83,6 \%$ & $-175,6 \%$ \\
\hline F30-34 & $-44,0 \%$ & $-941,7 \%$ & $68,9 \%$ & $367,2 \%$ & $-53,7 \%$ & $-1330,1 \%$ & $39,1 \%$ & $-477,7 \%$ & $-37,1 \%$ & $1244,2 \%$ & $-41,8 \%$ & $-320,8 \%$ & $-48,3 \%$ & $-410,2 \%$ & $3,0 \%$ & $-269,3 \%$ \\
\hline F35-39 & $-70,4 \%$ & $127,9 \%$ & $-37,9 \%$ & $29,5 \%$ & $-87,7 \%$ & $50,2 \%$ & $-135,9 \%$ & $-36,0 \%$ & $-48,1 \%$ & $-239,6 \%$ & $-159,1 \%$ & $192,6 \%$ & $-67,3 \%$ & $-138,4 \%$ & $-84,7 \%$ & $48,6 \%$ \\
\hline F40-44 & $12,5 \%$ & $117,7 \%$ & $55,3 \%$ & $-108,4 \%$ & $-242,6 \%$ & $-51,0 \%$ & $17,5 \%$ & $60,3 \%$ & $-281,5 \%$ & $-131,9 \%$ & $-55,6 \%$ & $163,2 \%$ & $-159,8 \%$ & $-62,2 \%$ & $-36,1 \%$ & $-29,7 \%$ \\
\hline F45-49 & $90,8 \%$ & $15,8 \%$ & $-126,5 \%$ & $-9,9 \%$ & $54,0 \%$ & $-9,0 \%$ & $-314,1 \%$ & $19,5 \%$ & $-98,5 \%$ & $-141,6 \%$ & $-40,1 \%$ & $-52,4 \%$ & $75,6 \%$ & $-40,6 \%$ & $-66,8 \%$ & $-67,3 \%$ \\
\hline F50-54 & $-123,2 \%$ & $94,1 \%$ & $-105,4 \%$ & $15,1 \%$ & $-224,0 \%$ & $182,8 \%$ & $-12,7 \%$ & $70,9 \%$ & $-61,5 \%$ & $-20,2 \%$ & $-173,6 \%$ & $118,6 \%$ & $-92,1 \%$ & $-88,3 \%$ & $-61,6 \%$ & $19,5 \%$ \\
\hline F55-59 & $-4244,5 \%$ & $136,2 \%$ & $-3750,4 \%$ & $-28,4 \%$ & $770,7 \%$ & $46,9 \%$ & $-894,3 \%$ & $-51,4 \%$ & $1455,2 \%$ & $34,2 \%$ & $-4288,1 \%$ & $80,6 \%$ & $-1854,9 \%$ & $46,0 \%$ & $-2078,9 \%$ & $-36,5 \%$ \\
\hline F60-64 & $-33,3 \%$ & $400,3 \%$ & $-22,3 \%$ & $107,7 \%$ & $-105,9 \%$ & $22,1 \%$ & $-56,7 \%$ & $-128,9 \%$ & $-21,3 \%$ & $37,2 \%$ & $-23,5 \%$ & $184,5 \%$ & $-90,4 \%$ & $170,9 \%$ & $-68,8 \%$ & $166,2 \%$ \\
\hline F65-69 & $-59,4 \%$ & $3238,3 \%$ & $3,5 \%$ & $1775,4 \%$ & $-29,9 \%$ & $2528,0 \%$ & $19,6 \%$ & $2098,0 \%$ & $63,4 \%$ & $1733,3 \%$ & $-34,9 \%$ & $3517,7 \%$ & $69,0 \%$ & $2401,6 \%$ & $33,3 \%$ & $4873,1 \%$ \\
\hline F70-74 & $-82,0 \%$ & $43,2 \%$ & $-23,9 \%$ & $50,7 \%$ & $-57,7 \%$ & $-9,6 \%$ & $-24,2 \%$ & $-47,8 \%$ & $-65,7 \%$ & $-108,6 \%$ & $-65,9 \%$ & $-21,4 \%$ & $-30,9 \%$ & $44,8 \%$ & $-47,2 \%$ & $136,7 \%$ \\
\hline F75-79 & $44,9 \%$ & $-9,5 \%$ & $223,1 \%$ & $1,7 \%$ & $275,7 \%$ & $298,6 \%$ & $136,8 \%$ & $-34,4 \%$ & $-23,1 \%$ & $10,5 \%$ & $58,7 \%$ & $10,6 \%$ & $141,5 \%$ & $41,9 \%$ & $170,3 \%$ & $139,6 \%$ \\
\hline F80 & $-124,6 \%$ & $62,2 \%$ & $40,7 \%$ & $206,2 \%$ & $120,7 \%$ & $25,3 \%$ & $75,5 \%$ & $-47,7 \%$ & $-84,1 \%$ & $-24,6 \%$ & $18,9 \%$ & $127,3 \%$ & $-1,7 \%$ & $309,6 \%$ & $-15,1 \%$ & $217,5 \%$ \\
\hline M16-19 & $-106,9 \%$ & $-18,3 \%$ & $-182,4 \%$ & $15,0 \%$ & $-23,8 \%$ & $-133,1 \%$ & $-132,1 \%$ & $-798,6 \%$ & $-158,3 \%$ & $-496,5 \%$ & $-121,3 \%$ & $441,3 \%$ & $-111,4 \%$ & $-178,9 \%$ & $-98,1 \%$ & $-223,2 \%$ \\
\hline M20-24 & $266,5 \%$ & $-189,7 \%$ & $227,1 \%$ & $-306,2 \%$ & $180,0 \%$ & $-544,2 \%$ & $388,5 \%$ & $474,9 \%$ & $247,7 \%$ & $2939,0 \%$ & $393,2 \%$ & $-1233,4 \%$ & $348,8 \%$ & $-135,5 \%$ & $443,8 \%$ & $-38,5 \%$ \\
\hline M25-29 & $-29,8 \%$ & $-268,3 \%$ & $30,0 \%$ & $-168,1 \%$ & $20,2 \%$ & $-201,0 \%$ & $-64,1 \%$ & $237,8 \%$ & $-27,1 \%$ & $78,9 \%$ & $21,5 \%$ & $-150,4 \%$ & $1,8 \%$ & $-62,0 \%$ & $44,4 \%$ & $-114,7 \%$ \\
\hline M30-34 & $-33,4 \%$ & $-16,7 \%$ & $-33,9 \%$ & $-62,5 \%$ & $-11,8 \%$ & $88,9 \%$ & $4,7 \%$ & $-165,2 \%$ & $-18,2 \%$ & $-298,4 \%$ & $53,4 \%$ & $-70,3 \%$ & $92,6 \%$ & $-101,2 \%$ & $52,7 \%$ & $-60,5 \%$ \\
\hline M35-39 & $-65,7 \%$ & $0,1 \%$ & $-37,1 \%$ & $-86,6 \%$ & $-57,7 \%$ & $-46,5 \%$ & $-36,3 \%$ & $-60,2 \%$ & $-68,4 \%$ & $-135,2 \%$ & $-54,3 \%$ & $-81,9 \%$ & $-27,8 \%$ & $-106,8 \%$ & $-48,7 \%$ & $-73,8 \%$ \\
\hline M40-44 & $164,3 \%$ & $-18,5 \%$ & $649,2 \%$ & $15,2 \%$ & $-111,4 \%$ & $-37,3 \%$ & $-198,0 \%$ & $-164,9 \%$ & $-113,2 \%$ & $-88,3 \%$ & $-25,7 \%$ & $72,5 \%$ & $614,6 \%$ & $-128,5 \%$ & $136,8 \%$ & $-119,3 \%$ \\
\hline M45-49 & $-171,3 \%$ & $245,3 \%$ & $353,1 \%$ & $94,7 \%$ & $-160,6 \%$ & $896,6 \%$ & $6,6 \%$ & $296,1 \%$ & $-62,4 \%$ & $201,4 \%$ & $153,6 \%$ & $186,7 \%$ & $653,6 \%$ & $-121,8 \%$ & $257,5 \%$ & $170,7 \%$ \\
\hline M50-54 & $-1197,9 \%$ & $8,4 \%$ & $-2587,6 \%$ & $-113,7 \%$ & $-1463,6 \%$ & $18,1 \%$ & $-3110,4 \%$ & $-54,8 \%$ & $124,0 \%$ & $-113,1 \%$ & $1192,3 \%$ & $-102,0 \%$ & $872,0 \%$ & $-49,6 \%$ & $-3679,0 \%$ & $-58,6 \%$ \\
\hline M55-59 & $-123,0 \%$ & $-48,2 \%$ & $-49,5 \%$ & $-59,4 \%$ & $32,8 \%$ & $77,0 \%$ & $-23,4 \%$ & $-20,4 \%$ & $-114,3 \%$ & $-94,5 \%$ & $16,2 \%$ & $-147,8 \%$ & $-89,8 \%$ & $-83,3 \%$ & $19,7 \%$ & $-39,0 \%$ \\
\hline M60-64 & $-43,3 \%$ & $-227,3 \%$ & $28,4 \%$ & $-172,2 \%$ & $-119,3 \%$ & $-221,2 \%$ & $53,7 \%$ & $-39,0 \%$ & $-141,4 \%$ & $-21,1 \%$ & $-27,1 \%$ & $-147,1 \%$ & $-107,6 \%$ & $-91,6 \%$ & $-58,0 \%$ & $-218,0 \%$ \\
\hline M65-69 & $-17,2 \%$ & $-65,9 \%$ & $-10,3 \%$ & $389,1 \%$ & $-88,9 \%$ & $433,3 \%$ & $58,2 \%$ & $-258,1 \%$ & $-23,9 \%$ & $95,1 \%$ & $39,6 \%$ & $-429,9 \%$ & $3,3 \%$ & $-234,9 \%$ & $-34,1 \%$ & $-7,0 \%$ \\
\hline M70-74 & $163,4 \%$ & $616,5 \%$ & $359,9 \%$ & $27,3 \%$ & $144,5 \%$ & $460,8 \%$ & $337,2 \%$ & $-312,6 \%$ & $295,7 \%$ & $127,6 \%$ & $220,4 \%$ & $-372,1 \%$ & $265,3 \%$ & $-203,1 \%$ & $118,1 \%$ & $804,2 \%$ \\
\hline
\end{tabular}




\begin{tabular}{|c|c|c|c|c|c|c|c|c|c|c|c|c|c|c|c|c|}
\hline \multirow[b]{2}{*}{ M75-79 } & \multicolumn{2}{|c|}{ Andalucía } & \multicolumn{2}{|c|}{ Aragón } & \multicolumn{2}{|c|}{ Asturias } & \multicolumn{2}{|c|}{ Baleares } & \multicolumn{2}{|c|}{ Canarias } & \multicolumn{2}{|c|}{ Cantabria } & \multicolumn{2}{|c|}{ Castilla - La Mancha } & \multicolumn{2}{|c|}{ Castilla - León } \\
\hline & $18,4 \%$ & $-211,4 \%$ & $97,4 \%$ & $-507,6 \%$ & $38,6 \%$ & $-630,6 \%$ & $87,7 \%$ & $-134,6 \%$ & $20,5 \%$ & $80,7 \%$ & $-20,1 \%$ & $-21,3 \%$ & $47,3 \%$ & $-287,7 \%$ & $-35,5 \%$ & $-450,9 \%$ \\
\hline M80 & $-94,4 \%$ & $-282,2 \%$ & $-28,6 \%$ & $-1173,0 \%$ & $-105,1 \%$ & $-306,8 \%$ & $-24,1 \%$ & $313,7 \%$ & $-75,8 \%$ & $-711,7 \%$ & $-89,6 \%$ & $-191,3 \%$ & $-59,8 \%$ & $246,3 \%$ & $-30,0 \%$ & $-937,2 \%$ \\
\hline Illiterate & $-10,4 \%$ & $70205,3 \%$ & $-82,7 \%$ & $115983,6 \%$ & $6,0 \%$ & $-10833,3 \%$ & $-6,9 \%$ & $47511,4 \%$ & $-15,8 \%$ & $190453,2 \%$ & $59,1 \%$ & $42124,6 \%$ & $-9,4 \%$ & $448,4 \%$ & $64,1 \%$ & $12836,4 \%$ \\
\hline $\begin{array}{l}\text { Reads and } \\
\text { writes }\end{array}$ & $-40,9 \%$ & $-172,0 \%$ & $28,3 \%$ & $-259,4 \%$ & $-9,7 \%$ & $-103,6 \%$ & $-8,0 \%$ & $45,3 \%$ & $-35,2 \%$ & $-1199,7 \%$ & $-28,9 \%$ & $25,7 \%$ & $-28,1 \%$ & $-438,8 \%$ & $-59,4 \%$ & $-220,7 \%$ \\
\hline $\begin{array}{l}\text { Primary } \\
\text { School }\end{array}$ & $-30,7 \%$ & $49,3 \%$ & $14,8 \%$ & $-260,8 \%$ & $-27,0 \%$ & $-74,4 \%$ & $11,5 \%$ & $21,7 \%$ & $8,3 \%$ & $-260,3 \%$ & $-6,4 \%$ & $-185,0 \%$ & $-18,9 \%$ & $10,4 \%$ & $-25,4 \%$ & $-274,0 \%$ \\
\hline $\begin{array}{c}\text { Secondary } \\
\text { School }\end{array}$ & $-10,0 \%$ & $-982,0 \%$ & $112,1 \%$ & $-25,8 \%$ & $-13,2 \%$ & $-610,5 \%$ & $-32,8 \%$ & $-1798,9 \%$ & $-34,8 \%$ & $-175,4 \%$ & $-5,1 \%$ & $-684,3 \%$ & $77,1 \%$ & $-295,3 \%$ & $35,7 \%$ & $391,0 \%$ \\
\hline Married & $1,6 \%$ & $12,6 \%$ & $88,4 \%$ & $-105,0 \%$ & $-152,5 \%$ & $-313,5 \%$ & $175,9 \%$ & $36,6 \%$ & $-22,3 \%$ & $-97,7 \%$ & $73,3 \%$ & $-217,9 \%$ & $86,3 \%$ & $-120,7 \%$ & $63,6 \%$ & $-33,0 \%$ \\
\hline $\begin{array}{l}\text { Divorced / } \\
\text { Separated }\end{array}$ & $-159,0 \%$ & $-48,7 \%$ & $34,2 \%$ & $41,9 \%$ & $-450,1 \%$ & $-5,6 \%$ & $206,7 \%$ & $-95,5 \%$ & $-125,5 \%$ & $24,0 \%$ & $-284,9 \%$ & $103,4 \%$ & $196,6 \%$ & $-71,5 \%$ & $105,4 \%$ & $-42,6 \%$ \\
\hline Widow & $-77,7 \%$ & $-56,2 \%$ & $21,4 \%$ & $-55,0 \%$ & $55,2 \%$ & $-386,2 \%$ & $36,0 \%$ & $145,1 \%$ & $-22,2 \%$ & $-32,2 \%$ & $-5,0 \%$ & $-251,2 \%$ & $-44,8 \%$ & $-135,8 \%$ & $-11,2 \%$ & $-20,4 \%$ \\
\hline Employed & $7,5 \%$ & $-72,3 \%$ & $16,2 \%$ & $-29,1 \%$ & $-31,4 \%$ & $-50,2 \%$ & $-11,6 \%$ & $-2,7 \%$ & $-14,6 \%$ & $-47,4 \%$ & $-9,5 \%$ & $-83,5 \%$ & $33,4 \%$ & $-85,7 \%$ & $12,1 \%$ & $-71,8 \%$ \\
\hline Pensioner & $-8,9 \%$ & $-1,7 \%$ & $38,7 \%$ & $-69,9 \%$ & $-23,9 \%$ & $-97,0 \%$ & $52,1 \%$ & $66,0 \%$ & $-9,9 \%$ & $-42,5 \%$ & $13,1 \%$ & $89,2 \%$ & $12,8 \%$ & $60,1 \%$ & $-13,8 \%$ & $-26,0 \%$ \\
\hline Unemployed & $-5,7 \%$ & $-84,1 \%$ & $9,9 \%$ & $-117,2 \%$ & $-23,7 \%$ & $-15,2 \%$ & $-68,0 \%$ & $41,9 \%$ & $28,5 \%$ & $-399,2 \%$ & $57,7 \%$ & $-255,0 \%$ & $-12,2 \%$ & $-113,4 \%$ & $-80,7 \%$ & $-144,4 \%$ \\
\hline Student & $-184,3 \%$ & $-89,1 \%$ & $-364,9 \%$ & $-37,3 \%$ & $-217,6 \%$ & $-111,0 \%$ & $-238,2 \%$ & $-78,0 \%$ & $-176,0 \%$ & $-20,9 \%$ & $-252,1 \%$ & $-108,5 \%$ & $-106,9 \%$ & $-42,4 \%$ & $-156,0 \%$ & $-74,2 \%$ \\
\hline
\end{tabular}


Table 5 (continued): Relative excess elasticity and inequality (vs País Vasco) of determinants per region

\begin{tabular}{|c|c|c|c|c|c|c|c|c|c|c|c|c|c|c|c|c|}
\hline & \multicolumn{2}{|c|}{ Catalonia } & \multicolumn{2}{|c|}{ Valencia } & \multicolumn{2}{|c|}{ Extremadura } & \multicolumn{2}{|c|}{ Galicia } & \multicolumn{2}{|c|}{ Madrid } & \multicolumn{2}{|c|}{ Murcia } & \multicolumn{2}{|c|}{ Navarra } & \multicolumn{2}{|c|}{ La Rioja } \\
\hline & $\mathrm{CI}$ & Elasticity & $\mathrm{CI}$ & Elasticity & CI & Elasticity & $\mathrm{CI}$ & Elasticity & $\mathrm{CI}$ & Elasticity & $\mathrm{CI}$ & Elasticity & CI & Elasticity & CI & Elasticity \\
\hline Log Income & $8,5 \%$ & $2376,3 \%$ & $7,1 \%$ & $903,8 \%$ & $8,0 \%$ & $671,4 \%$ & $9,6 \%$ & $2006,1 \%$ & $13,0 \%$ & $3474,5 \%$ & $6,9 \%$ & $2340,9 \%$ & $-2,8 \%$ & $-431,5 \%$ & $9,0 \%$ & $205,4 \%$ \\
\hline F20-24 & $-1186,6 \%$ & $-65,3 \%$ & $-1083,3 \%$ & $-50,5 \%$ & $-306,4 \%$ & $-134,5 \%$ & $-56,2 \%$ & $-188,2 \%$ & $-1124,8 \%$ & $18,9 \%$ & $-1769,1 \%$ & $-98,2 \%$ & $-1170,4 \%$ & $210,7 \%$ & $-803,0 \%$ & $-138,1 \%$ \\
\hline F25-29 & $-53,0 \%$ & $-318,7 \%$ & $-47,9 \%$ & $-195,5 \%$ & $-53,7 \%$ & $189,3 \%$ & $-66,0 \%$ & $-26,7 \%$ & $-60,3 \%$ & $-159,8 \%$ & $-81,3 \%$ & $-14,6 \%$ & $10,5 \%$ & $-117,6 \%$ & $-52,0 \%$ & $-52,6 \%$ \\
\hline F30-34 & $62,4 \%$ & $-808,4 \%$ & $-61,2 \%$ & $-563,0 \%$ & $11,1 \%$ & $1026,7 \%$ & $67,5 \%$ & $-38,4 \%$ & $65,6 \%$ & $-504,2 \%$ & $-41,0 \%$ & $418,0 \%$ & $37,9 \%$ & $-1652,3 \%$ & $17,2 \%$ & $409,1 \%$ \\
\hline F35-39 & $-44,5 \%$ & $90,0 \%$ & $-65,0 \%$ & $-80,1 \%$ & $-131,6 \%$ & $-285,5 \%$ & $-132,9 \%$ & $-153,1 \%$ & $-161,8 \%$ & $124,5 \%$ & $-56,0 \%$ & $-113,5 \%$ & $26,6 \%$ & $-103,4 \%$ & $-17,0 \%$ & $8,9 \%$ \\
\hline F40-44 & $-85,3 \%$ & $66,1 \%$ & $-144,9 \%$ & $54,6 \%$ & $-107,1 \%$ & $-90,1 \%$ & $-4,8 \%$ & $-76,0 \%$ & $-73,2 \%$ & $2,5 \%$ & $52,2 \%$ & $-177,0 \%$ & $33,1 \%$ & $-19,6 \%$ & $-99,6 \%$ & $-61,1 \%$ \\
\hline F45-49 & $-21,5 \%$ & $-8,5 \%$ & $-180,2 \%$ & $-29,8 \%$ & $-343,6 \%$ & $-118,8 \%$ & $-160,9 \%$ & $-57,4 \%$ & $-105,6 \%$ & $63,6 \%$ & $261,9 \%$ & $-40,2 \%$ & $-235,1 \%$ & $34,7 \%$ & $-509,8 \%$ & $-68,4 \%$ \\
\hline F50-54 & $-115,5 \%$ & $167,6 \%$ & $-12,2 \%$ & $44,4 \%$ & $-196,5 \%$ & $78,9 \%$ & $-14,8 \%$ & $-47,3 \%$ & $-36,7 \%$ & $129,9 \%$ & $-184,1 \%$ & $83,1 \%$ & $-17,8 \%$ & $87,3 \%$ & $-117,8 \%$ & $5,6 \%$ \\
\hline F55-59 & $-6165,0 \%$ & $111,4 \%$ & $-2710,5 \%$ & $-38,0 \%$ & $1603,5 \%$ & $-92,6 \%$ & $-1601,7 \%$ & $-26,6 \%$ & $-4401,9 \%$ & $-38,7 \%$ & $-2459,5 \%$ & $35,4 \%$ & $-1660,8 \%$ & $-52,4 \%$ & $-2795,0 \%$ & $-61,5 \%$ \\
\hline F60-64 & $-73,9 \%$ & $102,6 \%$ & $-37,6 \%$ & $234,3 \%$ & $-51,6 \%$ & $245,2 \%$ & $-69,0 \%$ & $125,4 \%$ & $-79,4 \%$ & $237,3 \%$ & $-104,4 \%$ & $-116,7 \%$ & $-14,3 \%$ & $127,2 \%$ & $-62,2 \%$ & $64,5 \%$ \\
\hline F65-69 & $22,4 \%$ & $524,7 \%$ & $2,0 \%$ & $2202,6 \%$ & $-49,0 \%$ & $1731,5 \%$ & $-61,6 \%$ & $2700,2 \%$ & $45,8 \%$ & $2655,9 \%$ & $1,7 \%$ & $-1038,7 \%$ & $6,8 \%$ & $2450,4 \%$ & $93,0 \%$ & $2039,7 \%$ \\
\hline F70-74 & $-18,6 \%$ & $-20,7 \%$ & $-11,3 \%$ & $-2,7 \%$ & $-69,7 \%$ & $-31,9 \%$ & $-52,8 \%$ & $-52,1 \%$ & $-13,0 \%$ & $23,7 \%$ & $-32,6 \%$ & $-95,4 \%$ & $-6,2 \%$ & $24,1 \%$ & $-33,2 \%$ & $-42,6 \%$ \\
\hline F75-79 & $209,2 \%$ & $122,9 \%$ & $48,0 \%$ & $98,8 \%$ & $-36,9 \%$ & $53,2 \%$ & $22,4 \%$ & $149,8 \%$ & $172,5 \%$ & $72,6 \%$ & $44,5 \%$ & $121,8 \%$ & $176,8 \%$ & $19,5 \%$ & $21,3 \%$ & $130,0 \%$ \\
\hline F80 & $18,6 \%$ & $134,6 \%$ & $-26,3 \%$ & $89,1 \%$ & $-52,0 \%$ & $43,7 \%$ & $-10,9 \%$ & $150,8 \%$ & $17,0 \%$ & $111,1 \%$ & $-10,1 \%$ & $37,0 \%$ & $18,0 \%$ & $104,6 \%$ & $57,8 \%$ & $71,5 \%$ \\
\hline M16-19 & $-247,9 \%$ & $-51,2 \%$ & $-149,4 \%$ & $48,3 \%$ & $-102,6 \%$ & $-397,1 \%$ & $-34,9 \%$ & $-475,7 \%$ & $-29,1 \%$ & $180,2 \%$ & $-151,9 \%$ & $-66,3 \%$ & $-233,7 \%$ & $-17,1 \%$ & $-97,8 \%$ & $-197,9 \%$ \\
\hline M20-24 & $255,5 \%$ & $-33,4 \%$ & $563,0 \%$ & $-1069,1 \%$ & $334,6 \%$ & $539,9 \%$ & $416,8 \%$ & $-280,9 \%$ & $371,6 \%$ & $393,7 \%$ & $133,0 \%$ & $1096,0 \%$ & $453,3 \%$ & $-79,3 \%$ & $376,3 \%$ & $197,4 \%$ \\
\hline M25-29 & $-0,9 \%$ & $-252,0 \%$ & $-4,5 \%$ & $-181,6 \%$ & $45,7 \%$ & $70,1 \%$ & $7,3 \%$ & $38,0 \%$ & $-26,0 \%$ & $-90,9 \%$ & $-57,3 \%$ & $37,0 \%$ & $47,9 \%$ & $-220,6 \%$ & $3,5 \%$ & $69,6 \%$ \\
\hline M30-34 & $79,2 \%$ & $-4,3 \%$ & $5,9 \%$ & $7,2 \%$ & $-20,7 \%$ & $-241,8 \%$ & $-44,3 \%$ & $-96,6 \%$ & $0,7 \%$ & $-35,5 \%$ & $24,6 \%$ & $-220,5 \%$ & $55,9 \%$ & $6,1 \%$ & $16,3 \%$ & $-152,1 \%$ \\
\hline M35-39 & $-79,2 \%$ & $-74,3 \%$ & $-77,6 \%$ & $-64,4 \%$ & $-44,2 \%$ & $-143,2 \%$ & $-73,2 \%$ & $-43,1 \%$ & $-73,9 \%$ & $-50,2 \%$ & $-111,5 \%$ & $-176,0 \%$ & $-101,9 \%$ & $-101,8 \%$ & $-34,9 \%$ & $-139,4 \%$ \\
\hline M40-44 & $356,8 \%$ & $30,6 \%$ & $-92,5 \%$ & $-78,8 \%$ & $399,3 \%$ & $-181,2 \%$ & $112,3 \%$ & $-75,2 \%$ & $70,6 \%$ & $-65,1 \%$ & $776,8 \%$ & $-212,7 \%$ & $741,5 \%$ & $-3,6 \%$ & $249,5 \%$ & $-123,3 \%$ \\
\hline M45-49 & $434,0 \%$ & $243,9 \%$ & $-14,0 \%$ & $104,7 \%$ & $-341,8 \%$ & $-343,1 \%$ & $43,6 \%$ & $-101,0 \%$ & $220,8 \%$ & $452,0 \%$ & $-178,6 \%$ & $-445,8 \%$ & $481,1 \%$ & $-57,2 \%$ & $270,2 \%$ & $-141,8 \%$ \\
\hline M50-54 & $747,7 \%$ & $-54,5 \%$ & $526,0 \%$ & $40,6 \%$ & $-110,8 \%$ & $-46,7 \%$ & $-3035,5 \%$ & $-62,3 \%$ & $-225,8 \%$ & $-60,1 \%$ & $817,7 \%$ & $-114,0 \%$ & $2487,7 \%$ & $4,4 \%$ & $-2705,9 \%$ & $-57,7 \%$ \\
\hline M55-59 & $-185,0 \%$ & $-34,0 \%$ & $-31,1 \%$ & $8,6 \%$ & $-59,8 \%$ & $-146,9 \%$ & $-120,9 \%$ & $-23,6 \%$ & $-24,9 \%$ & $-43,8 \%$ & $-208,0 \%$ & $-124,6 \%$ & $-250,5 \%$ & $68,5 \%$ & $-157,6 \%$ & $-66,2 \%$ \\
\hline M60-64 & $-166,4 \%$ & $-96,3 \%$ & $-136,8 \%$ & $-229,3 \%$ & $63,0 \%$ & $-128,2 \%$ & $40,4 \%$ & $-127,8 \%$ & $-68,9 \%$ & $-189,7 \%$ & $-13,3 \%$ & $-231,8 \%$ & $-127,8 \%$ & $-124,8 \%$ & $-77,2 \%$ & $-138,5 \%$ \\
\hline M65-69 & $-25,6 \%$ & $64,8 \%$ & $-43,6 \%$ & $212,0 \%$ & $36,7 \%$ & $-565,6 \%$ & $17,9 \%$ & $-129,1 \%$ & $-73,0 \%$ & $257,3 \%$ & $56,9 \%$ & $-64,7 \%$ & $-37,9 \%$ & $216,6 \%$ & $-29,9 \%$ & $-146,9 \%$ \\
\hline M70-74 & $104,8 \%$ & $-76,3 \%$ & $168,8 \%$ & $350,6 \%$ & $273,5 \%$ & $-424,9 \%$ & $132,1 \%$ & $658,4 \%$ & $258,9 \%$ & $94,6 \%$ & $209,3 \%$ & $17,8 \%$ & $247,9 \%$ & $253,3 \%$ & $365,1 \%$ & $326,8 \%$ \\
\hline M75-79 & $88,9 \%$ & $-7,1 \%$ & $-50,7 \%$ & $-578,0 \%$ & $45,5 \%$ & $-58,7 \%$ & $22,7 \%$ & $-380,6 \%$ & $-80,2 \%$ & $-256,2 \%$ & $86,8 \%$ & $-111,1 \%$ & $99,8 \%$ & $-332,9 \%$ & $73,7 \%$ & $-181,8 \%$ \\
\hline
\end{tabular}




\begin{tabular}{|c|c|c|c|c|c|c|c|c|c|c|c|c|c|c|c|c|}
\hline \multirow[b]{2}{*}{ M80 } & \multicolumn{2}{|c|}{ Catalonia } & \multicolumn{2}{|c|}{ Valencia } & \multicolumn{2}{|c|}{ Extremadura } & \multicolumn{2}{|c|}{ Galicia } & \multicolumn{2}{|c|}{ Madrid } & \multicolumn{2}{|c|}{ Murcia } & \multicolumn{2}{|c|}{ Navarra } & \multicolumn{2}{|c|}{ La Rioja } \\
\hline & $0,8 \%$ & $-274,3 \%$ & $-97,3 \%$ & $-531,1 \%$ & $-32,8 \%$ & $-584,7 \%$ & $-63,2 \%$ & $-705,5 \%$ & $-97,4 \%$ & $-442,5 \%$ & $-55,6 \%$ & $-582,3 \%$ & $-16,7 \%$ & $-789,6 \%$ & $-70,3 \%$ & $-1132,6 \%$ \\
\hline Illiterate & $-0,3 \%$ & $103167,2 \%$ & $-25,7 \%$ & $70582,7 \%$ & $-19,9 \%$ & $316765,5 \%$ & $61,3 \%$ & $13340,8 \%$ & $25,4 \%$ & $44271,9 \%$ & $-16,6 \%$ & $280105,3 \%$ & $-83,8 \%$ & $-1236,0 \%$ & $-72,6 \%$ & $11822,6 \%$ \\
\hline $\begin{array}{l}\text { Reads and } \\
\text { writes }\end{array}$ & $14,1 \%$ & $-348,9 \%$ & $4,6 \%$ & $-459,2 \%$ & $-15,5 \%$ & $-304,2 \%$ & $-24,6 \%$ & $-678,3 \%$ & $12,3 \%$ & $-32,4 \%$ & $16,9 \%$ & $-444,9 \%$ & $61,9 \%$ & $-168,3 \%$ & $-55,0 \%$ & $-479,0 \%$ \\
\hline $\begin{array}{l}\text { Primary } \\
\text { School }\end{array}$ & $15,5 \%$ & $-210,9 \%$ & $-20,9 \%$ & $-12,3 \%$ & $-72,4 \%$ & $-73,2 \%$ & $-17,8 \%$ & $-169,2 \%$ & $23,9 \%$ & $2,3 \%$ & $-14,2 \%$ & $-15,6 \%$ & $20,7 \%$ & $-113,0 \%$ & $3,1 \%$ & $-257,8 \%$ \\
\hline $\begin{array}{c}\text { Secondary } \\
\text { School }\end{array}$ & $28,9 \%$ & $-79,6 \%$ & $47,0 \%$ & $-384,7 \%$ & $22,5 \%$ & $-535,7 \%$ & $0,5 \%$ & $-280,3 \%$ & $-68,8 \%$ & $-518,7 \%$ & $9,0 \%$ & $-637,6 \%$ & $85,3 \%$ & $170,3 \%$ & $28,6 \%$ & $43,7 \%$ \\
\hline Married & $-68,6 \%$ & $-86,2 \%$ & $-44,6 \%$ & $-51,4 \%$ & $194,2 \%$ & $-125,1 \%$ & $25,6 \%$ & $-18,6 \%$ & $118,2 \%$ & $118,0 \%$ & $85,0 \%$ & $-188,6 \%$ & $220,6 \%$ & $-87,1 \%$ & $68,8 \%$ & $-99,7 \%$ \\
\hline $\begin{array}{l}\text { Divorced / } \\
\text { Separated }\end{array}$ & $-56,7 \%$ & $-126,8 \%$ & $-301,7 \%$ & $-20,3 \%$ & $210,8 \%$ & $25,5 \%$ & $-50,5 \%$ & $-96,3 \%$ & $-103,2 \%$ & $-53,0 \%$ & $-65,2 \%$ & $16,1 \%$ & $-277,6 \%$ & $-114,3 \%$ & $-11,6 \%$ & $-84,7 \%$ \\
\hline Widow & $41,9 \%$ & $11,9 \%$ & $-11,6 \%$ & $-137,5 \%$ & $-77,3 \%$ & $297,2 \%$ & $-17,8 \%$ & $33,9 \%$ & $-1,2 \%$ & $-74,0 \%$ & $-24,7 \%$ & $-136,6 \%$ & $7,4 \%$ & $-115,1 \%$ & $-21,7 \%$ & $126,4 \%$ \\
\hline Employed & $-14,3 \%$ & $-71,5 \%$ & $-2,9 \%$ & $-24,4 \%$ & $-6,0 \%$ & $-34,7 \%$ & $-13,2 \%$ & $-21,1 \%$ & $-16,1 \%$ & $19,1 \%$ & $-30,3 \%$ & $-61,5 \%$ & $15,4 \%$ & $-81,2 \%$ & $3,1 \%$ & $-129,4 \%$ \\
\hline Pensioner & $23,6 \%$ & $57,1 \%$ & $-17,6 \%$ & $-106,8 \%$ & $-2,0 \%$ & $94,7 \%$ & $12,8 \%$ & $-62,5 \%$ & $-9,0 \%$ & $-113,7 \%$ & $26,8 \%$ & $87,3 \%$ & $40,1 \%$ & $-65,3 \%$ & $29,4 \%$ & $-29,6 \%$ \\
\hline Unemployed & $-68,7 \%$ & $-143,2 \%$ & $8,2 \%$ & $46,2 \%$ & $-58,3 \%$ & $39,8 \%$ & $-38,1 \%$ & $-76,1 \%$ & $-23,2 \%$ & $59,4 \%$ & $24,7 \%$ & $-37,9 \%$ & $-31,6 \%$ & $-243,3 \%$ & $-68,3 \%$ & $-204,5 \%$ \\
\hline Student & $-277,2 \%$ & $-65,2 \%$ & $-221,8 \%$ & $-10,5 \%$ & $-198,4 \%$ & $-19,0 \%$ & $-235,9 \%$ & $-37,5 \%$ & $-147,1 \%$ & $26,2 \%$ & $-386,1 \%$ & $-25,8 \%$ & $-317,2 \%$ & $-62,4 \%$ & $-25,8 \%$ & $-96,3 \%$ \\
\hline
\end{tabular}




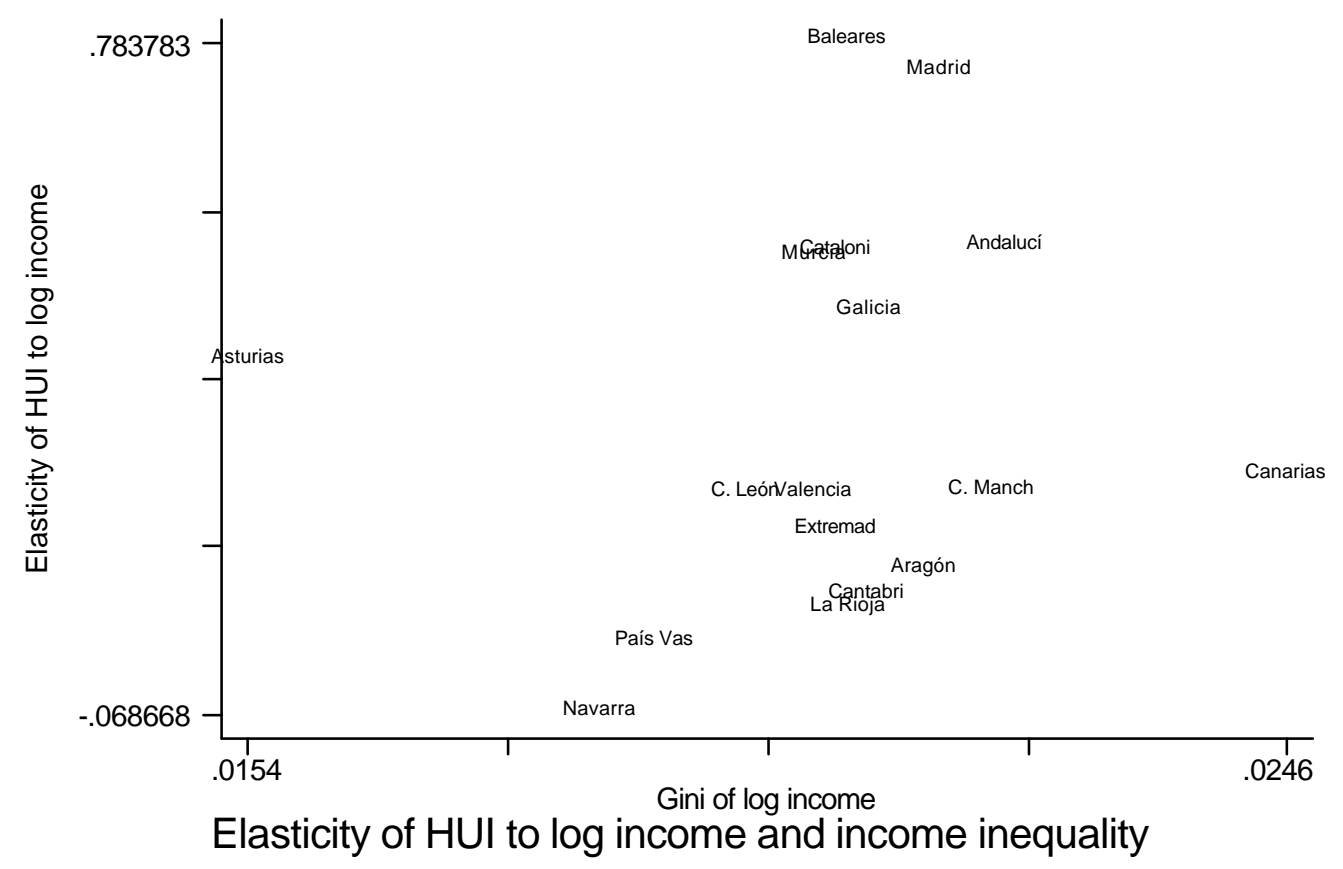

Graph 1. Elasticity of HUI to log income and income inequality 


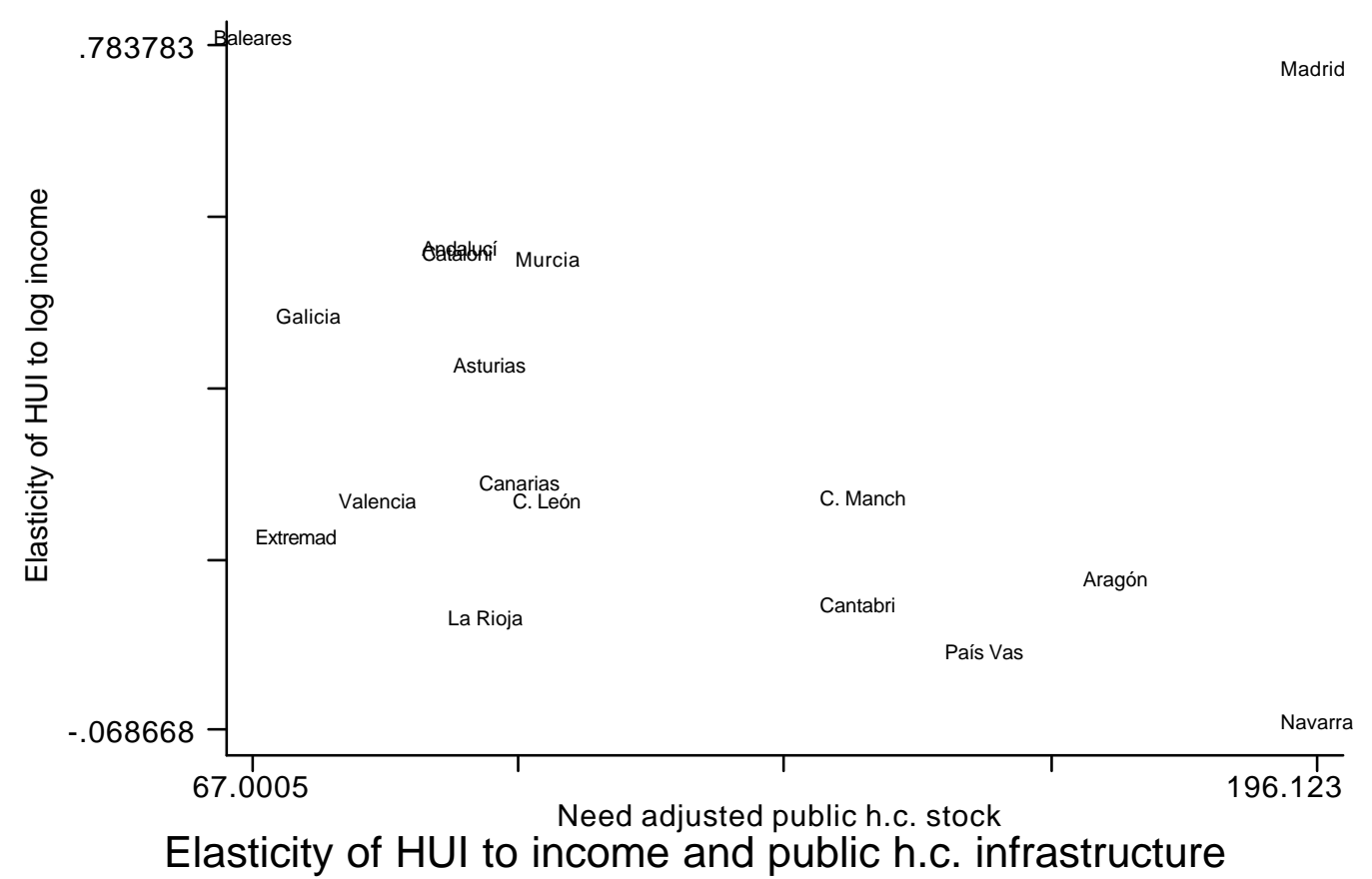

G raph 2. Relationship between the elasticity of HUI to equivalised log household income and an index of public health care infrastructure adjusted by need. 